Originally published as:

Demory, F., Oberhänsli, H., Nowaczyk, N. R., Gottschalk, M., Wirth, R., Naumann, R.

(2005): Detrital input and early diagenesis in sediments from Lake Baikal revealed by rock magnetism. - Global and Planetary Change, 46, 1-4, 145-166.

DOI: 10.1016/j.gloplacha.2004.11.010. 


\section{Detrital input and early diagenesis in sediments from Lake Baikal revealed by rock magnetism}

François Demory ${ }^{(1)}$, Hedi Oberhänsli ${ }^{(1)}$, Norbert R. Nowaczyk ${ }^{(1)}$, Matthias Gottschalk ${ }^{(2)}$, Richard Wirth $^{(2)}$ \& Rudolf Neumann ${ }^{(3)}$

GeoForschungsZentrum, Telegrafenberg, 14473 Potsdam, Germany.

(1) Section 3.3, Climate Dynamics and Sediments

(2) Section 4.1, Experimental petrology and geochemistry

(3) Section 4.2, Inorganic and Isotope Geochemistry

* Present Address: Centre Sed-Pal, FRE 2761, Université de Provence, place Victor Hugo, 13331 Marseille Cedex 03, France.(demory@up.univ-mrs.fr/fax +33-4-91-10-85-23)

\section{Abstract}

A rock magnetic study was performed on sediment cores from 6 locations in Lake Baikal. For a comprehensive approach of the processes influencing the rock magnetic signal, additional data are presented such as total organic carbon (TOC), total sulphur (TS), opal, water content and relative variations in iron and titanium measured on selected intervals. In glacial sediments the magnetic signal is dominated by magnetite, which is considered to be of detrital origin. This predominance of magnetite is interrupted by distinct horizons of authigenic greigite, probably confined to reductive microenvironments. In interglacial stages, besides dilution by biogenic silica and a decreasing detrital input, the weakness of the rock magnetic signal is also due to a reductive dissolution of magnetic particles. The magnetic assemblage is strongly linked to the redox history of interglacial sediment. In the oxidised bottom sediments of Lake Baikal, a biogenic magnetite is observed (Peck and King, 1996). After burial under the redox front the magnetite is preferentially dissolved and detrital hematite remains dominant when the sedimentation rate is low and when the residence time of the magnetite close to the redox boundary is long. During these low sedimentation rate conditions, the redox front is preserved (Granina et al., 2004). At constant sedimentation rate and fast burial, the magnetite is preserved or transformed into greigite when sulphate reducing conditions are reached in the sediment. In interglacial sediments, the magnetic assemblages depict changes in the sedimentation rate, which are traced using the ratio of magnetite over hematite (Sratio). At the beginning of interglacials, the sedimentation rate is constant with an assemblage 
magnetite + greigite (high S-ratio) and at the end of some interglacials the sedimentation rate decreases with a predominance of hematite (low S-ratio).

Keywords: Lake Baikal - Late Quaternary - Rock magnetism - Diagenesis - Detrital input

\section{Introduction}

Using rock magnetism, we can reconstruct the entire depositional history of magnetic particles in lake sediments. The magnetic minerals assemblage in sediments is first of all influenced by weathering and transport processes occurring in the catchement areas. After deposition, magnetic minerals can be altered, depending on chemical and biogenic processes occurring at the water/sediment interface and during diagenesis (e.g. Verosub, 1977; Snowball, 1993). In addition, during laboratory storage of the cores, the magnetic signal may also be altered (Thompson et al., 1980; Hilton, 1987). If diagenetic features such as dissolution and neoformation of magnetic particles can be identified and ruled out, rock magnetic properties become a powerful tool for tracing climate dynamics (e.g. Thouveny et al., 1994).

Since Lake Baikal sedimentation sensitively traces climate changes (Colman et al., 1995), it has been a natural laboratory for rock magnetic studies. However, rock magnetism was mainly used as a correlation tool since the concentration of magnetic minerals reflects the lithological variations in the sediment (e.g. Sakai et al., 2000; Kravchinsky et al., 2003). Specific studies identified fine-grained biogenic magnetite as one carrier of the magnetic signal in bottom sediments (Peck and King, 1996), which may however be susceptible to reductive diagenesis (Snowball, 1994). Peck et al. (1994) have also shown that magnetic properties are linked to climatic variations with biogenic dilution during interglacial periods and with the increase of terrigenous high coercivity minerals during glacial periods. For postdepositional processes, Dearing et al. (1998) have shown a weak reductive diagenesis.

The goal of this study is to better understand the links between detrital input, biogenic productivity and early diagenesis, which influence the rock-magnetic signal. This in turn allows us to validate the paleomagnetic variations recorded in Lake Baikal sediments (Demory et al. this issue), while ensuring a more critical interpretation of the signal carried by rock magnetic parameters. For this purpose, we carefully defined the magnetic mineralogy of different sediment cores of Lake Baikal and compared them to other sediment characteristics such as organic carbon, water, opal, iron and titanium contents. 


\section{Material and methods}

Lake Baikal (eastern Siberia) is a rift valley lake located at $51^{\circ} \mathrm{N}-56^{\circ} \mathrm{N}$ and $104^{\circ} \mathrm{E}-110^{\circ} \mathrm{E}$. It consists of three deep basins separated by two ridges (Fig. 1) with a $7.5 \mathrm{~km}$ thick sediment cover accumulated since the Miocene (Hutchinson et al., 1992). The major catchment area of Lake Baikal is located to the east-southeast. The hinterland is mainly composed of batholiths largely of granitic composition (e.g. Antipin, 1997), which provide many kinds of magnetic minerals. The Lake Baikal sediments are built up from detrital input and biogenic productivity, which are modulated by climatic conditions. The biogenic silica production is very low during glacial/stadial periods and high during interglacial/interstadial periods and outlines, therefore, the climatic variations associated with the expansion and retrait of northern hemisphere ice sheets (BDP-93 and Members, 1994; Colman et al., 1995; Grachev et al., 1997; Prokopenko et al., 2001).

Six sites were cored on geomorphologic highs on the margins of the basins (Fig. 1), to be far from turbiditic and river influences. Hence, the detrital input is mainly influenced by westerly and local winds, which are also likely to be the main source of transport for eolian sediment input into Baikal. Three piston and two pilot cores retrieved from three sites at Academician Ridge during a coring campaign in 1998 and three piston and three pilot cores retrieved during a coring campaign in 2001 were investigated (Table 1). Coring locations of 2001 are the Continent Ridge close to the northern basin (site CON01-603), the Posolsky Bank between the central and the southern basin (site CON01-604) and the Vydrino Shoulder on the southern flank of the southern basin (site CON01CON01-605). Due to the coring method, the uppermost sediments of the piston cores were lost. Where possible, the sedimentary column was completed by a combination of pilot and piston cores (see Demory et al., this issue).

Rock magnetic samples were continuously taken using $6.2 \mathrm{~cm}^{3}$ cubic plastic boxes (Table 1). The anisotropy of magnetic susceptibility (AMS) was measured using a Kappabridge KLY-3S (AGICO Brno, Czech Rep.). The AMS ellipsoid is characterised by its three principal axes $\mathrm{k}_{\max }, \mathrm{k}_{\mathrm{in}}, \mathrm{k}_{\min }$, and their dip and azimuth. The AMS orientation gives, as a first approximation, the preferred orientation of the magnetic grains and therefore the orientation of the sedimentary fabric (e.g. Rees, 1965; Frank et al., 2002). In unlaminated sediments, the orientation of the AMS axes indicates whether the coring is perpendicular to the sedimentary 
deposits, thereby allowing the determination as to whether there is any evidence for natural deformations of the sedimentary fabric. Furthermore the shape of the AMS ellipsoid is informative as an oblate shape is typical for compacted sediments whereas a prolate shape could reflect any deformation of the sedimentary fabric.

Low field magnetic susceptibility $\left(\kappa_{\mathrm{LF}}\right)$ was measured in order to estimate the contribution of ferrimagnetic particles in the sediments.

Anhysteretic remanent magnetisation (ARM) measurements, free of the effect of the dia-, para- and superparamagnetic components, provide an estimation of the magnetic remanence carriers, mainly of single domain (SD) grain size.

The isothermal remanent magnetisation (IRM) acquired in a $2 \mathrm{~T}$ direct current (DC) field using a pulse magnetiser, is defined as the saturation isothermal remanent magnetisation (SIRM). After applying this maximum field, all the samples were magnetised in a field of 300 $\mathrm{mT}$ in the opposite direction. The fraction of high-coercivity magnetic minerals was estimated by calculation of the ratio (Bloemendal et al., 1992):

$\mathrm{S}-$ ratio $=\frac{1}{2}\left(1-\frac{\mathrm{IRM}_{-0.3 \mathrm{~T}}}{\mathrm{SIRM}_{2 \mathrm{~T}}}\right)$

S-ratio values range from 0 to 1 . The value 1 is obtained for pure magnetite or greigite and decreases with increasing proportion of antiferromagnetic particles such as hematite.

The quantity of high coercivity minerals (hematite or goethite) was estimated by the High Isothermal Remnant Magnetisation HIRM, which results from the following relationship:

$\mathrm{HIRM}=\left(\mathrm{IRM}_{2 \mathrm{~T}}-\mathrm{IRM}_{0.3 \mathrm{~T}}\right) / 2$

This parameter has been used to estimate the detrital input, e.g. eolian input in ice records (Maher and Dennis, 2001) or in Lake Baikal sediments (Peck et al., 1994) despite discussions about its accuracy (Liu, 2002).

Hysteresis loops and backfield curves were determined for a representative population of samples using an Alterning Gradient Force Magnetometer (AGFM, Princeton Measurements Corp. model 2900 MicroMag). For this purpose, samples were freeze-dried and gently mortared, and mixed with an Agar jelly agent suspension and solidified in a $3 \times 3 \mathrm{~mm}$ cylindrical mould. The coercive force $\left(\mathrm{B}_{\mathrm{c}}\right)$ and the ratio of saturated remanent magnetisation $\left(\mathrm{M}_{\mathrm{rs}}\right)$ and saturation magnetisation $\left(\mathrm{M}_{\mathrm{s}}\right)$ were determined from the hysteresis loop measurements. The coercivity remanence $\left(B_{c r}\right)$ was deduced from the backfield curves of the saturated samples. The hysteresis parameters indicate the domain status of ferromagnetic 
particles (e.g. Day et al., 1977), which is linked to the absolute grain size and shape when magnetite dominates the signal (Dunlop, 2002a; Dunlop, 2002b).

High temperature measurements of magnetic susceptibility were performed on 13 representative samples using the same equipment as for $\kappa_{\mathrm{LF}}$ and AMS. Samples showing occurrence for greigite were especially targeted. Indeed, thermomagnetic measurements are generally performed on previously dried sediments whereas it is known that greigite can be unstable on contact with air (Oldfield et al., 1992). Therefore, relevant thermomagnetic curves were obtained only on wet sediments from the intervals where greigite was suspected. Thermomagnetic curves for these wet samples were determined using a "Variable Field Translation Balance" (VFTB), which is a combination of a Curie balance with a vibrating sample magnetometer (Nowaczyk et al., 2000). The measurement was performed at saturation magnetisation and in an argon atmosphere.

Magnetic extracts were analysed by X-ray diffraction and transmission electronic microscopy (TEM) using a STOE Stadi P diffractometer and a Philips CM200 transmission electron microscope respectively. Magnetic minerals were extracted from an interval dominated by magnetite at depth 527.5 to $529.9 \mathrm{~cm}$ (clay-rich layer) and one from an interval dominated by hematite at depth 583 to $590 \mathrm{~cm}$ (diatomaceous layer) in core VER 98-1-1. The extraction was done after removal of the organic carbon using a magnetic needle plunged in the sediment suspended in water in an ultrasonic bath. The goal was to better constrain the rock magnetic results where the $\mathrm{X}$-ray analysis gives a semi-quantitative characterisation the components of the magnetic extract (Rietveld structure refinement method using the program GSAS, see Larson and Von Dreele, 1987) and the TEM allows magnetic grain size to be directly observe and to proceed to elemental dispersive spectra on specific minerals.

We measured on the same cores water, opal, total organic carbon (TOC), total sulphur (TS), (relative) iron and (relative) titanium contents. The water content was determined from samples retrieved with cylindrical syringe samplers, weighed wet and weighed again after freeze-drying. Opal content was obtained by measuring the $\mathrm{NaCO}_{3}$ leached solution by inductive coupled plasma with an optical emission spectrometer (ICP-OES). Total organic carbon (TOC) and total sulphur (TS) were determined using a LECO CS-225-Analyser. A semi-quantitative estimate of titanium, iron and sulphur contents was obtained on selected intervals using X-ray fluorescence (XRF) logging at 2 mm steps (Jansen et al., 1998).

\section{Sedimentary fabric}


Visual screening of sediments to determine disturbances was successful whenever laminations occurred. As sediments of Lake Baikal are often unlaminated, we used estimate the bedding direction by measuring the orientation of magnetic minerals using AMS. The AMS data are plotted in a stereographic projection (Fig. 2). As most AMS data plot with long axes at $0^{\circ}$ and short axes at $90^{\circ}$, an overall horizontal stratification is evident. However for a few samples the short axis of AMS deviates from the vertical orientation indicating oblique laminations which are either due to coring artefacts as observed at the very top or bottom of the cores, or due to earthquake-induced slumps (Oberhänsli, 2000), with earthquakes being common in the Baikal rift valley (Sherman and Gladkov, 1999).

Furthermore, a slight preferential orientation parallel to the $0^{\circ}$ direction of the stereographic projection is observed for the long axis of magnetic anisotropy (Fig. 2). As the samples were not geographically oriented, we interpret this preferred orientation to be a sampling artefact resulting from a slight shearing when the plastic box penetrates the sediment during subsampling rather than indicating paleocurrent directions (Oda et al., 2002).

In conclusion, the AMS results document that the sediments under investigations are mostly undisturbed and given the oblate shape of the AMS ellipsoids (Fig. 2), compaction has been effective.

\section{Lithological variations and ARM}

The typical Baikal sedimentary succession consists of clay-rich layers alternating with diatomaceous layers, indicating glacial (cold) and interglacial (warm) periods, respectively (BDP-93 and Members, 1994; Colman et al., 1995; Grachev et al., 1997) (Fig. 3). The clayrich layers are characterised by a high ARM and low levels of TOC, TS, opal and water. The diatomaceous layers, indicating high biogenic productivity, show low ARM and high levels of TOC, TS, opal and pore water. Instead of using the magnetic susceptibility $\left(\kappa_{\mathrm{LF}}\right)$ for monitoring the varying concentration in magnetic minerals (e.g. Sakai et al., 2000), we used ARM to counter smoothing of the magnetic susceptibility signal by high contents in diamagnetic opal. Correlating the ARM from Lake Baikal cores with the orbitally tuned $\delta^{18} \mathrm{O}$ curve from ODP 677 (Shackleton et al., 1990), we identified marine isotope stages (MIS) (Fig. 3) and estimated the time span recorded in sediments.

The ARM records also allow cores from different sites across Lake Baikal to be correlated (Fig. 4). Sediment discontinuities as suggested by lithological descriptions at several 
transitions from interstadial to stadials are marked by abrupt changes in ARM. We show later in this paper that these periods of low or no sedimentation strongly influence the magnetic mineralogy.

\section{Magnetic mineralogy - Results}

Figure 4A shows variations of different rock magnetic parameters in one core in order to assess the magnetic mineralogy as described hereafter. The magnetic susceptibility does generally not exceed $500 \times 10^{-6} \mathrm{SI}$, except at certain depths where peak values are about one order of magnitude higher. The S-ratio is rather constant with values around 0.95 over the whole depth range. Still, some lower values of about 0.75 to 0.85 are observed, coinciding with low susceptibility values. At certain depths the S-ratio is close to 1, e.g. between 900 and $940 \mathrm{~cm} . \mathrm{SIRM} / \kappa_{\mathrm{LF}}$ is constantly low, apart from single peaks which correlate with the highest S-ratios. The parameter indicating an ARM loss between 50 and $65 \mathrm{mT}$ has a similar pattern than SIRM $/ \kappa_{\mathrm{LF}}$, but it is much more influenced by noise. The inclination of the acquired ARM is $\sim 90^{\circ}$, apart from some exceptions. Lower inclination occurs sporadically and correlates partly (e.g. at 890-940 cm) with S-ratio, SIRM/ $\kappa_{\mathrm{LF}}$ and $\mathrm{ARM}_{50 \mathrm{mT}}-\mathrm{ARM}_{65 \mathrm{mT}} / \mathrm{ARM}$ maxima. Figure $4 \mathrm{~B}$ shows that magnetic susceptibility is high in glacial and low in interglacial intervals. In addition it shows that the S-Ratio varies less in glacial sediments, ranging from 0.9 to 1 , than in interglacial sediments where the S-ratio is scattered from 0.7 to 1 .

In order to understand the previously described stratigraphic variations, we performed thermomagnetic analyses (susceptibility and induced magnetisation) from characteristic depths. Figure 5A shows the temperature dependence of magnetic low-field susceptibility for a sample from a clay-rich layer with a S-ratio of $\sim 0.95$, of $\sim 500 \times 10^{6}$ SI, low value $\mathrm{SIRM} / \kappa_{\mathrm{LF}}$ and no deviation of the ARM inclination. The susceptibility remains constant until $400^{\circ} \mathrm{C}$, then increases until a peak value at $\sim 560^{\circ} \mathrm{C}$ and decreases rapidly until $610^{\circ} \mathrm{C}$. The sample in Figure 5B originates from a diatomaceous layer (low susceptibility and S-ratio). The susceptibility decreases steadily until $670^{\circ} \mathrm{C}$, when the signal is lost. The samples in Figures 5C and 5D come from depths where almost all magnetic parameters have peaks values (see Figs. 4 and 12). Both graphs indicate a clear maximum at $300^{\circ} \mathrm{C}$. The magnetisation then decreases until $600^{\circ} \mathrm{C}$, above this temperature the magnetisation is zero. It should be noted that all curves are irreversible, indicating the thermal instability of the magnetic minerals present. 
Figure 6A shows hysteresis measurements of three samples with different S-ratios. The highest saturation magnetisation $\left(M_{s}\right)$ and coercive force $\left(B_{c}\right)$ was observed in the sample with a S-ratio $>0.95$, the lowest $\mathrm{M}_{\mathrm{s}}$ and $\mathrm{B}_{\mathrm{c}}$ in the sample with a S-ratio $<0.9$. In all cases the hysteresis curve is influenced by paramagnetism, the effect being largest in the sample with low S-ratio. The day plot (Fig. 6B) indicates that samples with S-ratios $>0.95$ plot rather in the single-domain (SD) to pseudo-single-domain (PSD) range. Samples with S-ratios between 0.9 and 0.95 instead, plot rather in the PSD to the multi-domain (MD) range. Low S-ratio samples are not greatly dispersed and have ratios of $B_{c r} / B_{c}$ and $M_{r s} / M_{s}$ of 3.5 and 0.1 respectively.

\section{Magnetic mineralogy - Interpretation}

Three different magnetic mineral populations seem to be present in the sediment cores from Lake Baikal. The temperature dependence of magnetic susceptibility indicates a magnetite/maghemite population for S-ratios between 0.9 and 0.95 , which is probably of detrital origin because it occurs in clay-rich sediments deposited during glacial-periods (Fig. 3). Energy dispersive X-ray spectroscopy (EDS) on transmission electronic microscopy (TEM) indicates an enhanced iron and oxygen content in analysed grains (Fig. 7), which are suggested to consist of iron oxides. The X-ray diffraction (XRD) spectra from magnetic extracts of clay-rich layers (Fig. 8A) support the previous suggestion, indicating magnetite as dominant mineral. S-ratios close to 1 indicate the absence of a high coercivity mineral component. The Curie temperature measurements (Figs. 5C and 5D) show a loss of remanence above $300^{\circ} \mathrm{C}$, which is typical for the mineral greigite (Roberts, 1995). The hysteresis loop indicates a coercive force of $\sim 45 \mathrm{mT}$, which is in agreement with greigite data from (Roberts, 1995), in line with other hysteresis parameters. Deflections from the ARM axis can be caused by a gyroremanent magnetisation acquired during static AF demagnetisation in anisotropic samples (Stephenson, 1980). Such gyroremanence has been identified in natural greigite samples (Hu et al., 1998; Stephenson and Snowball, 2001; Hu et al., 2002). According to Roberts (1995) and Oldfield (1998), both, a high SIRM/ $\kappa_{L F}$ and the absence of a hard remanence component in combination with strong gyroremanences, are typical for authigenic greigite.

The interpretation of samples with low S-ratios is rather difficult. Low S-ratios indicate the presence of a high coercivity component, i.e. grains with remanent coercive forces $>300 \mathrm{mT}$. We tend to interpret it as a signal of hematite, based on thermomagnetic curves (Fig. 5B), 
while the hysteresis loop contradicts the S-ratio. The measured coercive force $\left(\mathrm{B}_{\mathrm{c}}\right)$ in Figure $6 \mathrm{~A}$ (lowermost loop) is about $11 \mathrm{mT}$ only. According to the ratio $\mathrm{B}_{\mathrm{cr}} / \mathrm{B}_{\mathrm{c}}$ the remanent coercive force would be around $40 \mathrm{mT}$. Hematite with such small $\mathrm{B}_{\mathrm{c}}$ is of multi-domain size and about $1 \mathrm{~mm}$ in diameter (Kletetschka and Wasilewski, 2002) and should be remagnetised when applying an opposite field during the S-ratio procedure. Nevertheless, the S-ratio is low and we suggest that the presence of a certain amount of superparamagnetic magnetite/maghemite particles is lowering the coercive force. These superparamagnetic grains would not affect the S-ratio as they are not able to carry a remanent magnetisation. Indeed, the TEM microphotographs in Figure 7B, show that grains in the superparamagnetic grain size range are present in the diatomaceous layers. They are probably relics of biogenic magnetite, which has formed at the water/sediment interface, as has been described by Peck and King (1996). In addition, there are also grains containing titanium (Fig. 7C), indicating substitution of titanium for iron oxide. This is confirmed by XRD analysis (Fig. 8B), which shows a relative abundance of titanite and titanomagnetite while the magnetite content is much less.

\section{Discussion}

The magnetic mineralogy demonstrates that magnetite, probably of detrital origin, dominates the signal in most of the glacial sediments, except in a few intervals characterised by the presence of greigite. The interglacial sediments present different magnetic mineral assemblages with predominance of either magnetite (sometimes with greigite) or hematite. In this section, we compare the magnetic mineralogy with non-magnetic proxies such as water, opal, TOC, and TS wt \%, semi-quantitative Fe and Ti contents. These proxies trace the biogenic productivity and the detrital input, but are also indicative of early diagenetic conditions, which control e.g. the preservation of organic matter and the redox conditions, and would help to constrain the processes responsible for modifications in magnetic mineral assemblages.

\section{VII.1. Tracers of the detrital input}

In selected intervals, we measured titanium and iron contents in parallel to rock magnetic parameters (Fig. 9). Titanium content are a good reflection of detrital input since minerals 
containing titanium are not very sensitive to dissolution. Iron however is rather mobile and involved in the redox history of highly porous sediments: the spike of iron observed on top of the sedimentary column (Fig. 9A) marks the redox front. We observed a strong similarity between the titanium and HIRM curves: the detrital input decreases from the late glacial to the Holocene. In ancient sediments, HIRM and titanium display similar variations with high values in glacials and low values in interglacials (Fig. 9B). Notably, no significant HIRM change is observed at the transition between oxidising and reducing conditions in the sediment (Fig. 9A). This implies that HIRM is not affected by redox conditions and further confirms that the "hard" magnetic mineral content is the best tracer of detrital input (Peck et al., 1994). On the other hand, the S-ratio seems to be related to the redox conditions in the sediment (see section VII.2 below). The ARM has also to be considered with caution as it is mainly influenced by the ferrimagnetic contribution, which is itself influenced by post depositional processes. This is seen in Figure 9, where ARM variations are partly influenced by S-ratio variations.

\section{VII.2. Dissolution of magnetic minerals}

The difference by an order of magnitude between ARM values in glacial and interglacial sediments (Fig. 3) suggests the dissolution of magnetic minerals in the sediment. The observed difference cannot result only from low detrital input and dilution of the lithogenic component by opal (30 wt \%) and pore water (40 wt \%) (Fig. 3).

The topmost sediments are oxidised since the entire water column of Lake Baikal is oxygen saturated throughout the year (Weiss et al., 1991). High ARMs as well as high S-ratios in this oxidised zone (Fig. 9A) are partly due to fine-grained biogenic magnetite (Peck and King, 1996). The redox boundary between the oxic zone at the top and the anoxic zone below is marked by a downward decrease of the ARM and S-ratio values while the HIRM (i.e. the quantity of "hard" magnetic minerals such as hematite) remains constant. The decrease in the S-ratio is, therefore, due to a decrease of "soft" magnetic minerals (magnetite), which is linked to processes in the redox front and results from an in-situ process.

Processes driving selective dissolution of "soft" magnetic particles under suboxic and anoxic conditions in the pore water are still debated. In lakes characterised by sediments rich in organic carbon, hematite has been shown to dissolve first (Williamson et al., 1998). In subarctic lakes (Snowball, 1993) and in Lake Baikal (the present study), the fine grained magnetite dissolves easier than hematite under similar conditions with relatively low organic 
carbon contents (up to $2 \mathrm{wt} \%$ ) and low sedimentation rates. Due to high surface/volume ratio, the small grains of bio-magnetite (Peck and King, 1996) and magnetite, which underwent maghemitization under oxic/suboxic conditions, are very sensitive to dissolution processes (Smirnov and Tarduno, 2000). The dissolution of soft magnetic minerals (magnetite) after burial below the redox front is probably mediated by bacteria in the presence of organic carbon. We suggest two types of transformation in interglacial sediments of Lake Baikal. First, the dissolution of magnetic minerals is the main supplier of soluble $\mathrm{Fe}^{2+}$ feeding the redox front (Granina et al., 2004). Secondly, a high concentration of dissolved opal in the pore water facilitates the transformation of magnetite into smectite (Florindo et al., 2003). This would corroborate the occurrence of a secondary smectite in Lake Baikal sediments (Fagel et al., 2003).

The dissolution of soft magnetic minerals is observed in recent sediments but also in other interglacial sediments such as the Kazantsevo (equivalent to the Eemian in Europe) (Figure 9B). We observed low S-ratio below a peak of iron over titanium interpreted as a paleo-redox front. Therefore dissolution of soft magnetic minerals is a feature also observed in ancient interglacial sediments and may result from similar processes.

Nevertheless this dissolution is only observed at the end of some interglacial intervals. Dissolution events do not trace a basin-wide signal in Lake Baikal but result from local phenomena since they cannot be correlated from one core to another core. Furthermore, they are observed just below preserved paleo-redox fronts, as highlighted by spikes of iron over titanium (Fig. 9). The paleo-redox fronts are themselves observed just below zones of condensed sedimentation rates. Indeed, several studies have demonstrated a strong relationship between a decrease of the sedimentation rates and preservation of paleo-redox fronts (Deike et al., 1997; Granina et al., 2000; Granina et al., 2004). In the present study, there are further pieces of evidence for changes in the sedimentation rates. According to $A M S$ ${ }^{14} \mathrm{C}$ measurements (Piotrowska et al. in press) performed on a Kasten core taken at site CON01-603-2 and transferred to the present study by susceptibility correlation (Demory et al., this issue), a general decrease of the sedimentation rates was observed in the topmost section of the sedimentary column: $\sim 10 \mathrm{~cm} \mathrm{ky}^{-1}$ between 98 and $80 \mathrm{~cm}$ depth and $\sim 4.5 \mathrm{~cm}$ $\mathrm{ky}^{-1}$ between 25 and $2 \mathrm{~cm}$ depth. This decrease is likely to be underestimated since we have not considered the sediment compaction processes. Moreover, abrupt changes between interglacial and glacial sediments may be hiatuses, as in core VER 98-1-14, where we found many events of soft magnetic mineral dissolution and sediment discontinuities (Fig. 3). 
Changes in sedimentation rates are also observed in core VER 98-1-1 located on the slope between Academician Ridge and the central basin (Fig. 1). Interglacial intervals here are very thick and most probably related to redeposition events (Ceramicola et al., 2002), while glacial intervals have similar extension as determined from other cores at the Academician Ridge (Fig. 4). In this core also, the S-ratio decreases strongly on top of interglacial stages (Fig. 10).

Processes responsible for low sedimentation or hiatuses were suggested after high resolution seismic investigations. (Ceramicola et al., 2002) observed many events of winnowing which could be responsible for sedimentation rate decay, while local slumping cannot be neglected as a cause for hiatuses. The low cohesivity of the highly porous interglacial sediments would easily lead to a destabilisation of the sediments. A decay of the biogenic productivity (less opal input), which would not be immediately compensated by the glacial type detrital input, could be another reason for the sedimentation decrease at the end of interglacials.

\section{VII.3. Occurrence of greigite}

Authigenesis of greigite is another characteristic of the sedimentary sequences of Lake Baikal. As summarized by (Dekkers et al., 2000), the greigite can form diagenetically after deposition of sediments during bacterial reduction or when hydrothermal fluids are present. Greigite is more likely to grow beyond the redox front during sulphate reduction, although the influence of hydrothermal fluids activated in the tectonic setting of Lake Baikal cannot be ruled out. Increased presence of greigite (high SIRM $/ \kappa_{\mathrm{LF}}$ ) coincides with maximum sulphur contents observed at the beginning of interglacial stages (Fig. 11A). At similar levels in another sediment core of Lake Baikal, (Watanabe et al., 2004) observed pyrite mineralization. They attributed these pyrite-rich levels to mineralization at sediment/water interface under anoxic bottom water conditions. However, we prefer to interpret the greigite as a result of magnetite transformation when sulphate reduction occurs in the interglacial sediments. Peak sulphur contents would therefore be due to sulphur mineralisation within the sediment and would not result from an enrichment of the sediment in sulphur at the sediment/water interface.

Higher abundance of greigite during glacial intervals also coincides with small increases of the S content (Fig. 11B). Greigite levels in glacial sediments cannot be correlated between cores (Fig. 12), which suggests that greigite concentrations are driven by local processes. We suggest that faecal pellets could be a suitable microenvironment for sulphate reduction. And 
while greigite could potentially act as proxy for faecal pellets in glacial sediments, unfortunately we can not rely on this possible indicator since the greigite is very sensitive to onshore alterations after sampling (Snowball and Thompson, 1990).

\section{Conclusion}

Continuous rock magnetic measurements, complemented by X-ray diffraction and TEM on magnetic extracts, were performed on cores from Lake Baikal covering several glacial and interglacial stages. Compared to geochemical data, the rock magnetic study showed that:

(i) HIRM, i.e. hematite+goethite content, remains the best estimate for the detrital input in Lake Baikal, whereas parameters estimating the magnetic mineral concentration, like magnetic susceptibility or ARM, are partly influenced by post-depositional processes such as magnetic dissolution.

(ii) Magnetite dominates the magnetic signal in glacial sediments except for a few enhancements of greigite, probably confined to reductive microenvironments.

(iii) Magnetic assemblages vary in interglacial sediments with predominance of magnetite +greigite at the beginning of interglacial intervals and a predominance of hematite at the end of some of the interglacial intervals. For interglacial sediments, we propose a model of the magnetic signal involving mainly in situ processes. Due to less wind, the detrital input in Lake Baikal is low compared to the glacial, and therefore there are less detrital magnetic minerals as observed in the HIRM curves (Fig. 9). During interglacial stages the biogenic productivity is high and the bottom water of Lake Baikal is known to be well oxygenated. In the oxidised bottom sediments, a magnetite is generated by magnetotactic bacteria (Peck and King, 1996). After burial, the biomagnetite is passed by the redox front (rich in iron) and then stays in a suboxic to anoxic environment where organic carbon is preserved. In the case of a constant sedimentation rates, the burial is quite fast. Consequently, the magnetite could be preserved or transformed into Greigite once sulphate reduction occurs. This scenario is proposed for the beginning of the interglacials. A second scenario occurs when the sedimentation rate decreases. In this case, magnetite stays longer just below the redox front. This allows a slow dissolution of magnetite and a significant precipitation of iron at the redox front. This is expressed by the preservation of a paleo-redox front as observed in the present study as well as in previous studies (e.g. Deike et al. (1997); Granina et al. (2004)) and by low S-ratios, showing the preferential dissolution of soft magnetic minerals. 


\section{Acknowledgments}

This work was done in the frame of the project CONTINENT supported by the European Commission under contract EVK2-CT-2000-00057

We thank Frederich Heller, David Williamson and Simo Spassov for their fruitful comments on the manuscript. Holger Lippitz helped with AMS measurements and Sushma Prasad, Anon Mackay and Jens Klump for correcting the English. 
References:

Antipin, V.S., Tomilov, B.V., Goreglyad, A.V., Kovalenko, V.I., Budnikov, S.V., 1997. Chemical composition of granitoids of the Angara-Vitim batholith as a source of sediments in the eastern part of Lake Baikal. IPPCCE Newsletter, 10: 5-16.

BDP-93 and Members, B.D.P., 1994. First data of the First Drilling on Lake Baikal, Buguldeika Site, Southeastern Siberia. IPPCCE Newsletter, 8: 5-26.

Bloemendal, J., King, J.W., Hall, F.R. and Doh, S.-J., 1992. Rock magnetism of Late Neogene and Pleistocene deep-sea sediments: Relationship to sediment source, diagenetic processes, and sediment lithology. Journal of Geophysical Research, 97(b4): 4361-4375.

Ceramicola, S., Rebesco, M., De Batist, M. and Khlystov, O., 2002. Seismic evidence of small-scale lacustrine drifts in Lake Baikal (Russia). Marine Geophysical Researches, 22(5-6): 445-464.

Colman, S.M., Peck, J.A., Karabanov, E.B., Carter, S.J., Bradbury, J.P., King, J.W. and Williams, D.F., 1995. Continental climate response to orbital forcing from biogenic silica records in Lake Baikal. Nature, 378: 769-771.

Day, R., Fuller, M. and Schmidt, V.A., 1977. Hysteresis properties of titanomagnetites: grainsize and compositional dependance. Physics of the Earth and Planetary Interiors, 13: 260-267.

Dearing, J.A., Boyle, J.F., Appleby, P.G., Mackay, A.W. and Flower, R.J., 1998. Magnetic properties of recent sediments in Lake Baikal, Siberia. Journal of Paleolimnology, 20(2): 163-173.

Deike, R.G., Granina, L., Callender, E. and McGee, J.J., 1997. Formation of ferric iron crusts in Quarternary sediments of Lake Baikal, Russia, and implications for paleoclimate. Marine Geology, 139: 21-46.

Dekkers, M.J., Passier, H.F. and Schoonen, M.A.A., 2000. Magnetic properties of hydrothermally synthesized greigite $\left(\mathrm{Fe}_{3} \mathrm{~S}_{4}\right)$-II. High- and low-temperature characteristics. Geophysical Journal International, 141(3): 809-819.

Demory, F., Nowaczyk, N.R., Witt, A. and Oberhänsli, H., this issue. High-resolution magnetostratigraphy of late Quaternary sediments from Lake Baikal, Siberia: timing of intracontinental paleoclimatic responses. 
Dunlop, D.J., 2002a. Theory and application of the Day plot $\left(\mathrm{M}_{\mathrm{rs}} / \mathrm{M}_{\mathrm{s}}\right.$ versus $\left.\mathrm{H}_{\mathrm{cr}} / \mathrm{H}_{\mathrm{c}}\right) ; 1$, Theoretical curves and tests using titanomagnetite data. Journal of Geophysical Research, 107(B3): 10.1029/2001JB000486

Dunlop, D.J., 2002b. Theory and application of the Day plot $\left(\mathrm{M}_{\mathrm{rs}} / \mathrm{M}_{\mathrm{s}}\right.$ versus $\left.\mathrm{H}_{\mathrm{cr}} / \mathrm{H}_{\mathrm{c}}\right)$; 2 , Application to data for rocks, sediments, and soils. Journal of Geophysical Research, 107(B3): 10.1029/2001JB000487

Fagel, N., Boski, T., Likhoshway, L. and Oberhaensli, H., 2003. Late Quaternary clay mineral record in Central Lake Baikal (Academician Ridge, Siberia). Palaeogeography, Palaeoclimatology, Palaeoecology, 193: 159-179.

Florindo, F., P., R.A. and Palmer, M.R., 2003. Magnetite dissolution in siliceous sediments. Geochemistry, Geophysics, Geosystems, 4(7): 1-13.

Frank, U., Nowaczyk, N.R., Negendank, J.F.W. and Melles, M., 2002. A paleomagnetic record from Lake Lama, northern Central Siberia. Physics of the Earth and Planetary Interiors, 133(1-4): 3-20.

Grachev, M.A., Likhohway, E.V., Vorobieva, S.S., Khlystov, O.M., Bezrukova, E.V., Veinberg, E.V., Goldberg, E.L., Granina, L.Z., Kornakova, E.G., Lazo, F.I., Levina, O.V., Letunova, P.P., Otinov, P.V., Pirog, V.V., Fedotov, A.P., Yaskevitch, A.V., Bobrov, V.A., Sukhorukov, F.V., Rezchikov, V.I., Fedorin, M.A., Zolotarev, K.V. and Kravchinsky, V.A., 1997. Signals of the paleoclimates of upper Pleistocene in the sediments of Lake Baikal. Geologia i Geophysica, 38(5): 957-980.

Graham, J.W., 1966. Significance of magnetic anisotrophy in Appalachian sedimentary rocks, In: The earth beneath the continents--A volume of geophysical studies in honor of Merle A. Tuve. Geophysical Monograph American Geophysical Union. Washington, DC, United States., pp. 627-648.

Granina, L., Müller, B. and Wehrli, B., 2004. Origin and dynamics of Fe and Mn sedimentary layers in Lake Baikal. Chemical Geology, 205(1-2): 55-72.

Granina, L., Muller, B., Wehrli, B. and Martin, P., 2000. Oxygen, iron, and manganese at the sediment-water interface in Lake Baikal. Terra Nostra, 9: 87-94.

Hilton, J., 1987. A simple model for the interpretation of magnetic records in lacustrine and ocean sediments. Quaternary Research, 27(2): 160-166.

Hu, S., Appel, E., Hoffman, V., Schmahl, W. and Wang, S., 1998. Gyroremanent remanence acquired by greigite (Fe3S4) during static three-axis alternating field demagnetisation. Geophysical Journal International, 134(3): 831-842. 
Hu, S., Stephenson, A. and Appel, E., 2002. A study of gyroremanent magnetisation (GRM) and rotational remanent magnetisation (RRM) carried by greigite from lake sediments. Geophysical Journal International, 151(2): 469-474.

Hutchinson, D.R., Golmshtok, A., J.,, Zonenshain, L.P., Moore, T.C., Scholz, C.A. and Klitgord, K.D., 1992. Depositional and tectonic framework of the rift basins of Lake Baikal from multichannel seismic data. Geology, 20: 589-592.

Jansen, J.H.F., Van der Gaast, S.J., Koster, B. and Vaars, A.J., 1998. CORTEX, a shipboard XRF-scanner for element analyses in split sediment cores. Marine Geology, 151(1-4): 143-153.

Kletetschka, G. and Wasilewski, P.J., 2002. Grain size limit for SD hematite. Physics of The Earth and Planetary Interiors, 129(1-2): 173-179.

Kravchinsky, V.A., Krainov, M.A., Evans, M.E., Peck, J.A., King, J.W., Kusmin, M.I., Sakai, H., Kawai, T. and Williams, D.F., 2003. Magnetic record of Lake Baikal sediments: chronological and paleoclimatic implication for the last 6.7 Myr. Palaeogeography, Palaeoclimatology, Palaeoecology, 195: 281-298.

Larson, A.C. and Von Dreele, R.B., 1987. Generalized structure analysis system, Los Alamos National Laboratory Report: No. LA-UR-86-748.

Liu, Q.B., S.K.; Jackson, M.J.; Zhu, R.; Pan, Y., 2002. A new method in mineral magnetism for the separation of weakantiferromagnetic signal from a strong ferrimagnetic background. Geophysical Research Letters, 29(12): 6-1 - 6-4.

Maher, B.A. and Dennis, P.F., 2001. Evidence against dust-mediated control of glacialinterglacial changes in atmospheric $\mathrm{CO}_{2}$. Nature, 411(6834): 176-180.

Nowaczyk, N.R., Harwart, S. and Melles, M., 2000. A rock magnetic record from Lama Lake, Taymyr Peninsula, northern Central Siberia. Journal-of-Paleolimnology, 23(3): 227241.

Oberhänsli, H., 2000. Searching for climate proxies stored in Lake Baikal sediments: A few comments. Terra Nostra, 9: 140-147.

Oda, H., Nakamura, K., Ikehara, K., Nakano, T., Nishimura, M. and Khlystov, O., 2002. Paleomagnetic record from Academician Ridge, Lake Baikal: a reversal excursion at the base of marine oxygen isotope stage 6. Earth and Planetary Science Letters, 202(1): 117-132.

Oldfield, F., 1998. The rock magnetic identification of magnetic mineral and grain size assemblages. In: J. Walden, F. Oldfield and J. Smith (Editors), Environment magnetism, a practical guide. Quaternary Research Association, pp. 98-112. 
Oldfield, F., Darnley, I., Yates, G., France, D.E. and Hilton, J., 1992. Storage diagenesis versus sulphide authigenesis: possible implications in environmental magnetism. Journal of Paleolimnology, 7(3): 179-189.

Peck, J.A. and King, J.W., 1996. Magnetofossils in the sediments of lake Baikal, Siberia. Earth and Planetary Science Letters, 140(1-4): 159-172.

Peck, J.A., King, J.W., Colman, S.M. and Kravchinsky, V.A., 1994. A rock-magnetic record from Lake Baikal, Siberia: Evidence for Late Quarternary climate change. Earth and Planetary Science Letters, 122: 221-238.

Piotrowska, N., Bluszcz, A., Demske, D., Granoszewski, W. and Heumann, G., in press. Extraction and AMS radiocarbon dating of pollen from Lake Baikal sediments, Radiocarbon, 46.

Prokopenko, A.A., Karabanov, E.B., Williams, D.F., Kuzmin, M.I., Shackleton, N.J., Crowhurst, S.J., Peck, J.A., Gvozdkov, A.N. and King, J.W., 2001. Biogenic silica record of the lake baikal response to climatic forcing during the brunhes. Quaternary Research, 55(2): 123-132.

Rees, A.I., 1965. The use of anisotropy of magnetic susceptibility in the estimation of sedimentary fabric. Sedimentology, 4(4): 257-271.

Roberts, A.P., 1995. Magnetic properties of sedimentary greigite $\left(\mathrm{Fe}_{3} \mathrm{~S}_{4}\right)$. Earth and Planetary Science Letters, 134(3-4): 227-236.

Sakai, H., Nomura, S., Horii, M., Kashiwaya, K., Tanaka, A., Kawai, T., Kravchinsky, V., Peck, J. and King, J., 2000. Paleomagnetic and Rock-magnetic studies on Lake Baikal sediments -BDP96 borehole at Academician Ridge. In: K. Minoura (Editor), Lake Baikal. Elsevier Science B.V., pp. 35-52.

Shackleton, N.J., Berger, A. and Peltier, W.R., 1990. An alternative astronomical calibration of the lower Pleistocene timescale based on ODP site 677. Transactions of the Royal Society Edinburgh Earth Sciences, 81: 251-261.

Sherman, S.I. and Gladkov, A.S., 1999. Fractals in studies of faulting and seismicity in the Baikal rift zone. Tectonophysics, 308(1-2): 133-142.

Smirnov, A.V. and Tarduno, J.A., 2000. Low-temperature magnetic properties of pelagic sediments (Ocean Drilling Program Site 805C): Tracers of maghemitization and magnetic mineral reduction. Journal of Geophysical Research B: Solid-Earth, 105(7): $16,457-16,471$. 
Snowball, I.F., 1993. Geochemical control of magnetite dissolution in subarctic lake sediments and the implications for environmental magnetism. Journal of Quaternary Science, 8(4): 339-346.

Snowball, I.F., 1994. Bacterial magnetite and the magnetic properties of sediments in a Swedish lake. Earth and Planetary Science Letters, 126(1-3): 129-142.

Snowball, I.F. and Thompson, R., 1990. A stable chemical remanence in Holocene sediments. Journal of Geophysical Research, 95(B4): 4471-4479.

Stacey, F.D., Joplin, G. and Lindsay, J., 1960. Magnetic anisotropy and fabrics of some foliated rocks from S.E. Australia. Geofiz. Pura Appl., 47: 30-40.

Stephenson, A., 1980. A gyroremanent magnetisation in anisotropic magnetic material. Nature, 284: 49-51.

Stephenson, A. and Snowball, I.F., 2001. A large gyromagnetic effect in greigite. Geophysical Journal International, 145(2): 570-575.

Thompson, R., Bloemendal, J., Dearing, J.A., Oldfield, F., Rummery, T.A., Stober, J.C. and Turner, G.M., 1980. Environmental applications of magnetic measurements. Science, 207: 481-486.

Thouveny, N., de Beaulieu, J.-L., Bonifay, E., Creer, K.M., Guiot, J., Icole, M., Johnsen, S., Jouzel, J., Reille, M., Williams, T. and Williamson, D., 1994. Climate variations in Europe over the past $140 \mathrm{kyr}$ deduced from rock magnetism. Nature, 371: 503-506.

Verosub, K.L., 1977. Depositional and Postdepositional Processes in the Magnetization of Sediments. Reviews of Geophysics and Space Physics, 15(2): 129-143.

Watanabe, T., Naraoka, H., Nishimura, M. and Kawai, T., 2004. Biological and environmental changes in Lake Baikal during the late Quaternary inferred from carbon, nitrogen and sulfur isotopes. Earth and Planetary Science Letters, In Press.

Weiss, R.F., Carmack, E.C. and Koropalov, V.M., 1991. Deep-water renewal and biological production in Lake Baikal. Nature, 349: 665-669.

Williamson, D., Jelinowska, A., Kissel, C., Tucholka, P., Gibert, E., Gasse, F., Massault, M., Taieb, M., Van Campo, E. and Wieckowski, K., 1998. Mineral-magnetic proxies of erosion/oxidation cycles in tropical maar-lake sediments (Lake Tritrivakely, Madagascar): paleoenvironmental implications. Earth and Planetary Science Letters, 155(3-4): 205-219. 


\section{Figure Captions}

Figure 1: Simplified bathymetric map of Lake Baikal. The 6 core locations are marked by black dots.

Figure 2: Stereographic projection of the minimum $\left(\mathrm{k}_{\min }\right)$ and maximum $\left(\mathrm{k}_{\max }\right)$ axes of the AMS ellipsoid and diagram of the shape of the AMS ellipsoid (Stacey et al., 1960) versus the degree of magnetic anisotropy (Graham, 1966) for all cores.

Figure 3: Downcore variations of the ARM, TOC, water and opal content and simplified lithology for the sedimentary sequence of VER 98-1-14. Correlation to MIS using the $\delta^{18} \mathrm{O}$ variations measured in ODP Site 677 by (Shackleton et al., 1990). (Data available at: doi:10.1594/GFZ/ICDP/CON/2004....)

Figure 4: A. Downcore variations of rock magnetic parameters and simplified lithological description for the sedimentary sequence VER 98-1-14. Here MIS are denoted by numbers in the lithological column. The black squares filled intervals mark occurrences of greigite characterised by a high magnetic susceptibility $\left(\kappa_{\mathrm{LF}}\right)$ in parts with a low coercive mineral dominating the magnetic signal (S-ratio close to 1 ), a high SIRM/ $\kappa_{L F}$, a strong loss of ARM intensity between the demagnetisations steps 50 and $65 \mathrm{mT}$ and finally a deviation of the inclination of ARM. The dark grey intervals mark occurrences of magnetite dissolution with a low S-ratio resulting from relative higher hematite content in the ferromagnetic components. The assignment of greigite and dissolved magnetite is based on subsequent interpretation; B. Magnetic susceptibility $\left(\kappa_{\mathrm{LF}}\right)$ versus S-ratio for the sedimentary sequence VER 98-1-14 showing S-ratio gathered around 0.95 in glacial sediments and scattered from 0.7 to 1 in interglacial sediments. (Data available at: doi:10.1594/GFZ/ICDP/CON/2004....)

Figure 5: A. High temperature measurements of magnetic susceptibility in clay-rich layers: magnetite characterised by a Curie temperature of $590^{\circ} \mathrm{c}$ dominates the signal; $\mathrm{B}$. High temperature measurements of magnetic susceptibility in diatomaceous layers: most of the weak susceptibility is still present up to the temperature of $670^{\circ} \mathrm{C}$ and carried by hematite; $\mathrm{C}$. and D. High temperature measurements of the saturation magnetisation, both samples show a loss of a part of the signal at temperatures between 350 and $400^{\circ} \mathrm{C}$, typical disintegration 
temperatures for greigite. The remaining signal disappears above a temperature of $590^{\circ} \mathrm{C}$, typical for magnetite.

Figure 6: A. Three characteristic hysteresis loops uncorrected (to the left) and corrected for the paramagnetic influence (to the right). On top a single domain behaviour hysteresis loop for a sample with occurrence of greigite, in the middle a pseudo-single domain behaviour of the hysteresis loop from a clay-rich layer and below a pseudo-single to multi-domain behaviour of the hysteresis loop from a diatomaceous layer. B. Day plot (Day et al., 1977) of hysteresis parameters of representative samples with the boundaries between single-domain (SD), pseudo-single-domain (PSD) and multi-domain (MD) area. We classified the samples according to their S-ratio (see the three ellipses).

Figure 7: Representative transmission electron microphotographs and elemental dispersive spectra of magnetic extract. Oxides of different size (from submicron to micron) are visible on the microphotographs; A. in the clay-rich layer (interval 527.5 to $529.9 \mathrm{~cm}$, core VER 98-11), the extract is dominated by pure iron oxides (magnetite); B and C., in the diatomaceous layer (interval 583 to $590 \mathrm{~cm}$, core VER 98-1-1), there is a relative enrichment in titanium and chromium of the oxides.

Figure 8: X-ray diffraction patterns and semi-quantitative approach of the different phases for magnetic extracts; A. extract from the clay-rich layer (interval 527.5 to $529.9 \mathrm{~cm}$, core VER 98-1-1), characterised by $70 \%$ of magnetite and by a titanite poor in aluminium; B. extract from diatomaceous layer (interval 583 to $590 \mathrm{~cm}$, core VER 98-1-1), characterised by only 17 $\%$ of magnetite and by a titanite rich in aluminium.

Figure 9: Downcore variations of rock magnetic parameters (ARM, S-ratio and HIRM), and XRF titanium, iron counting and ratio Fe/Ti for two different sedimentary sequences, redox and paleo-redox fronts are highlighted in grey; A. section at site CON01-603-2 covering the Holocene and MIS 2, on the photo of the core the limit oxic/anoxic sediments is well documented; B. section at site VER 98-1-14 covering MIS 5d, Eemian and MIS 6. (Data available at: doi:10.1594/GFZ/ICDP/CON/2004_...) 
Figure 10: Downcore variations of the S-ratio and simplified lithological description. Here MIS are denoted by numbers in the lithological columns. The arrows show spikes of low Sratios

Figure 11: Downcore variations of sulphur and SIRM $/ \kappa_{\mathrm{LF}}$ (high values are considered to indicate greigite); A. topmost part of the sedimentary sequence from site CON01-603-2, relative sulphur content is estimated by XRF counting; B. Full record for sedimentary sequence from site VER98-1-14, total sulphur content. For A. and B. the grey lines show the correlation between increase of sulphur and presence of greigite. Two intervals are documented by radiographs showing the scattered distribution of the greigite in glacial sediments and the layer rich in sulphur at the transition glacial/interglacial.

Figure 12: Downcore variations of the $\mathrm{SIRM} / \kappa_{\mathrm{LF}}$ (high values are considered to indicate greigite) and simplified lithological description. Here MIS are denoted by numbers in the lithological columns. 


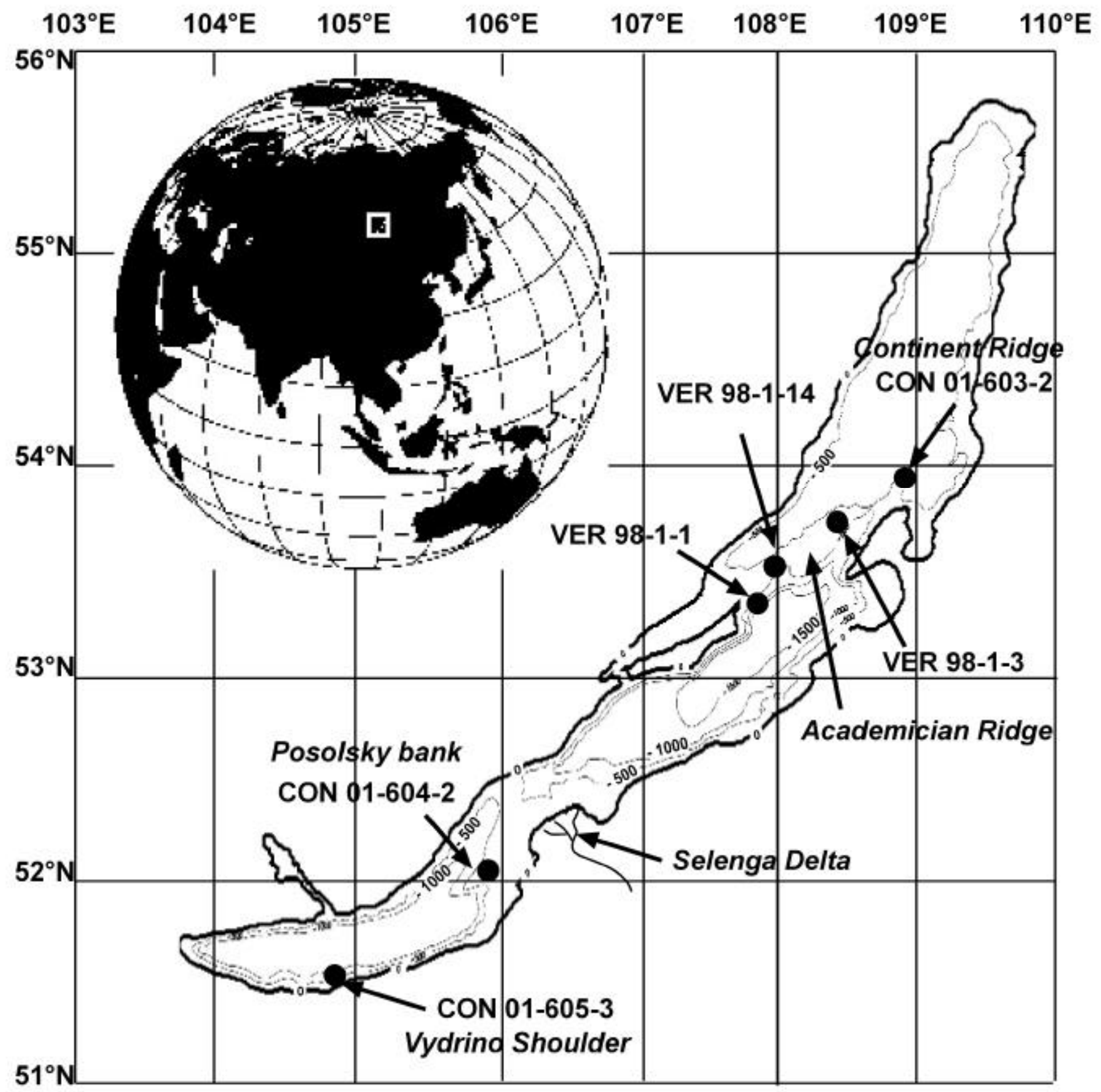

Fig1 


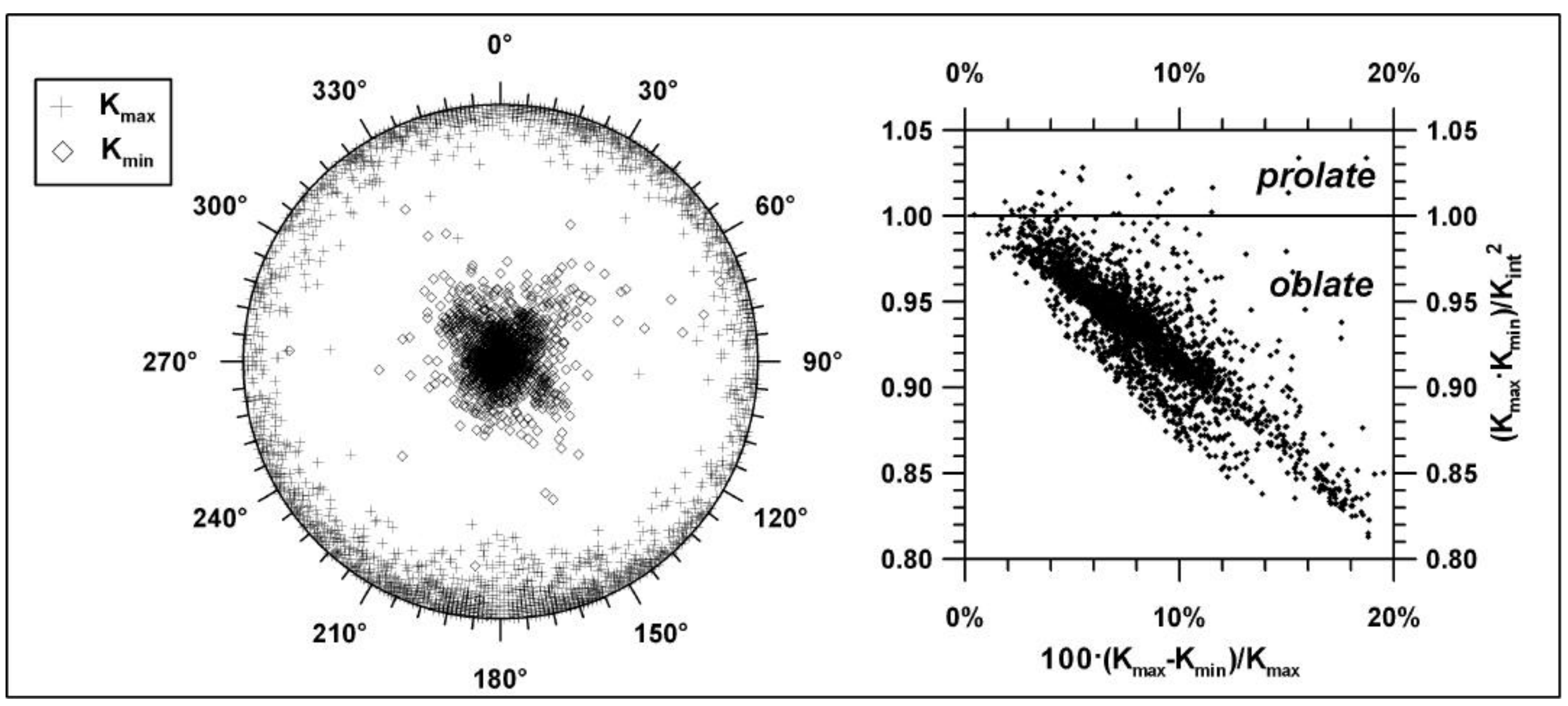




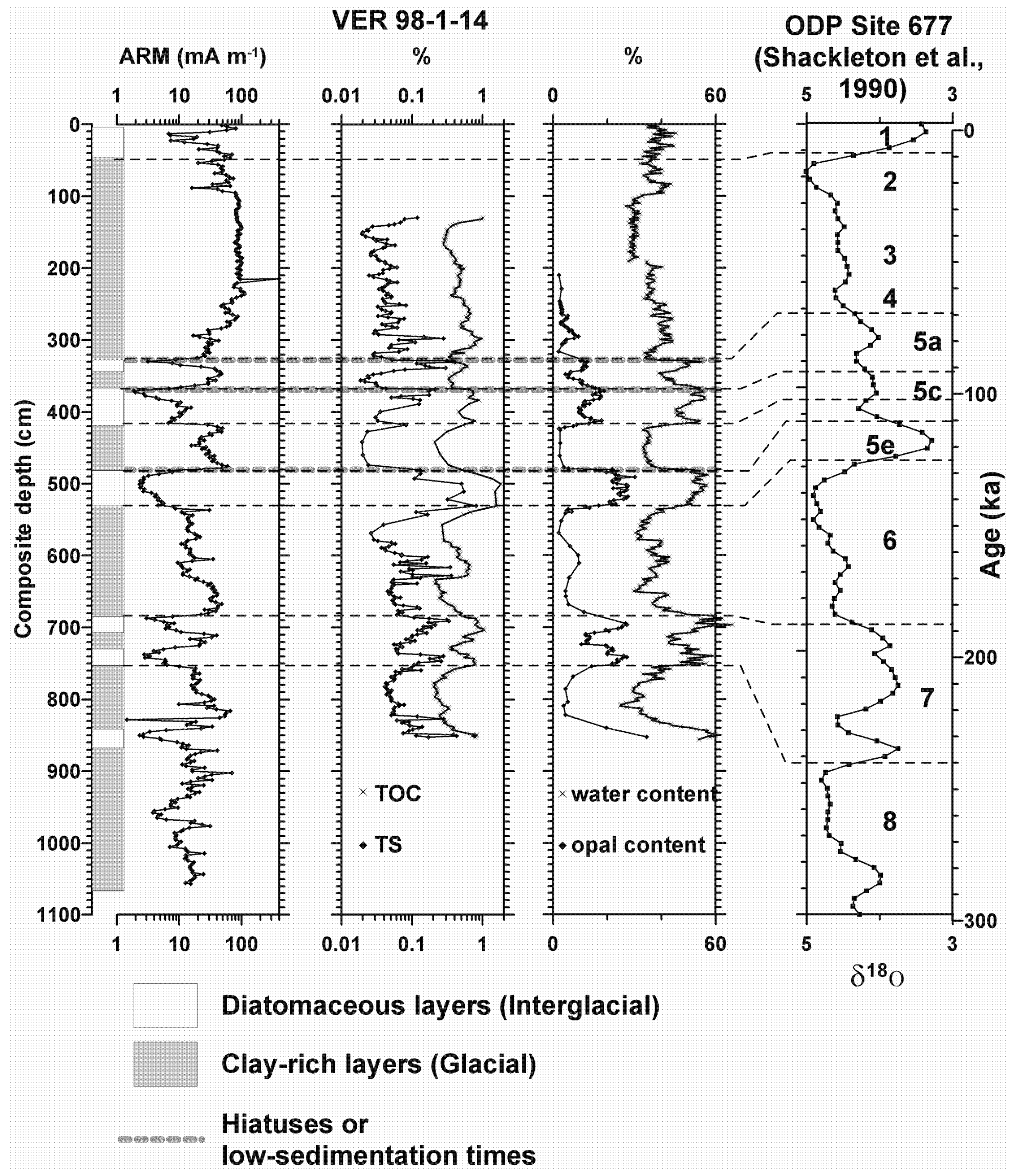




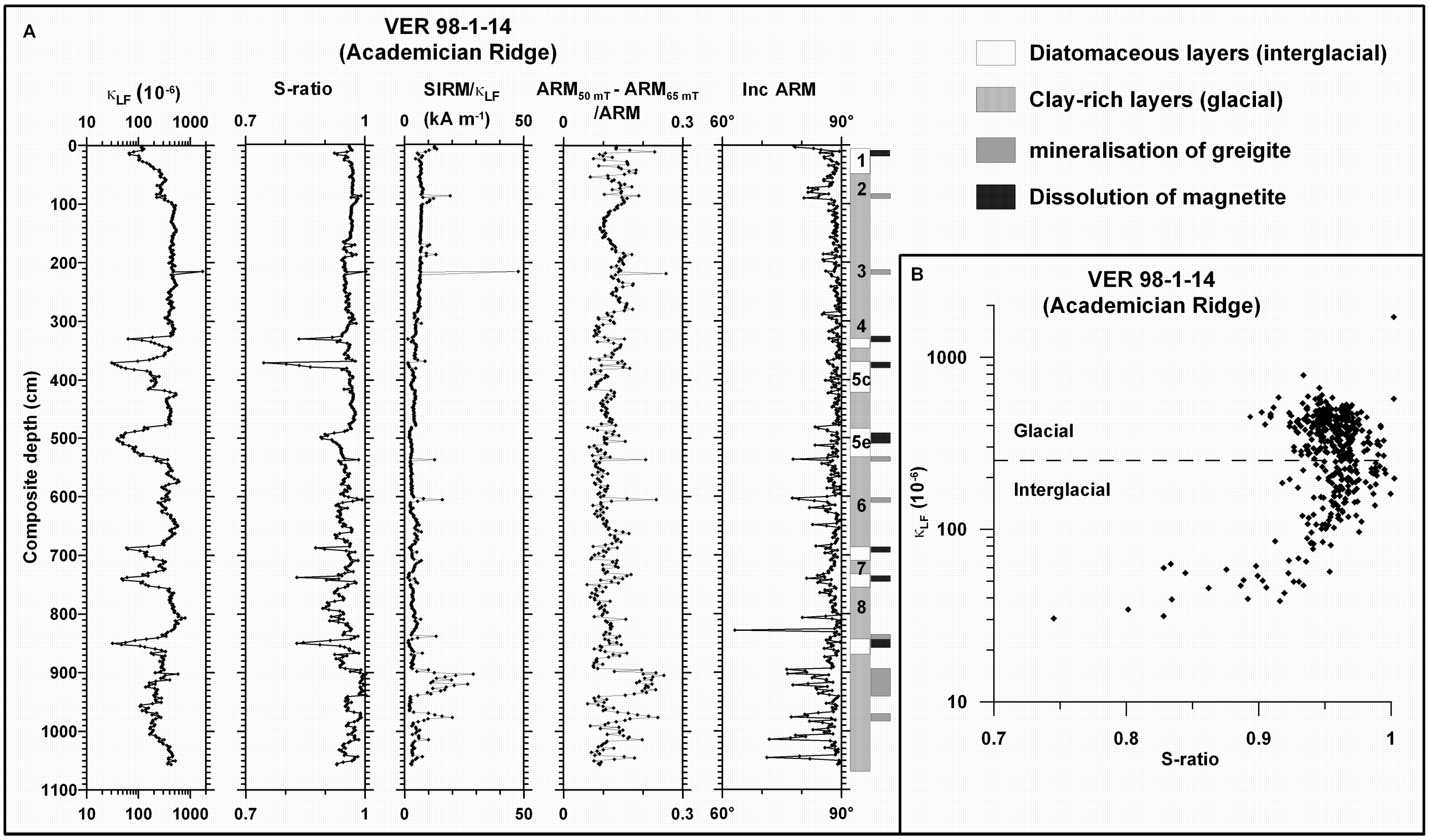



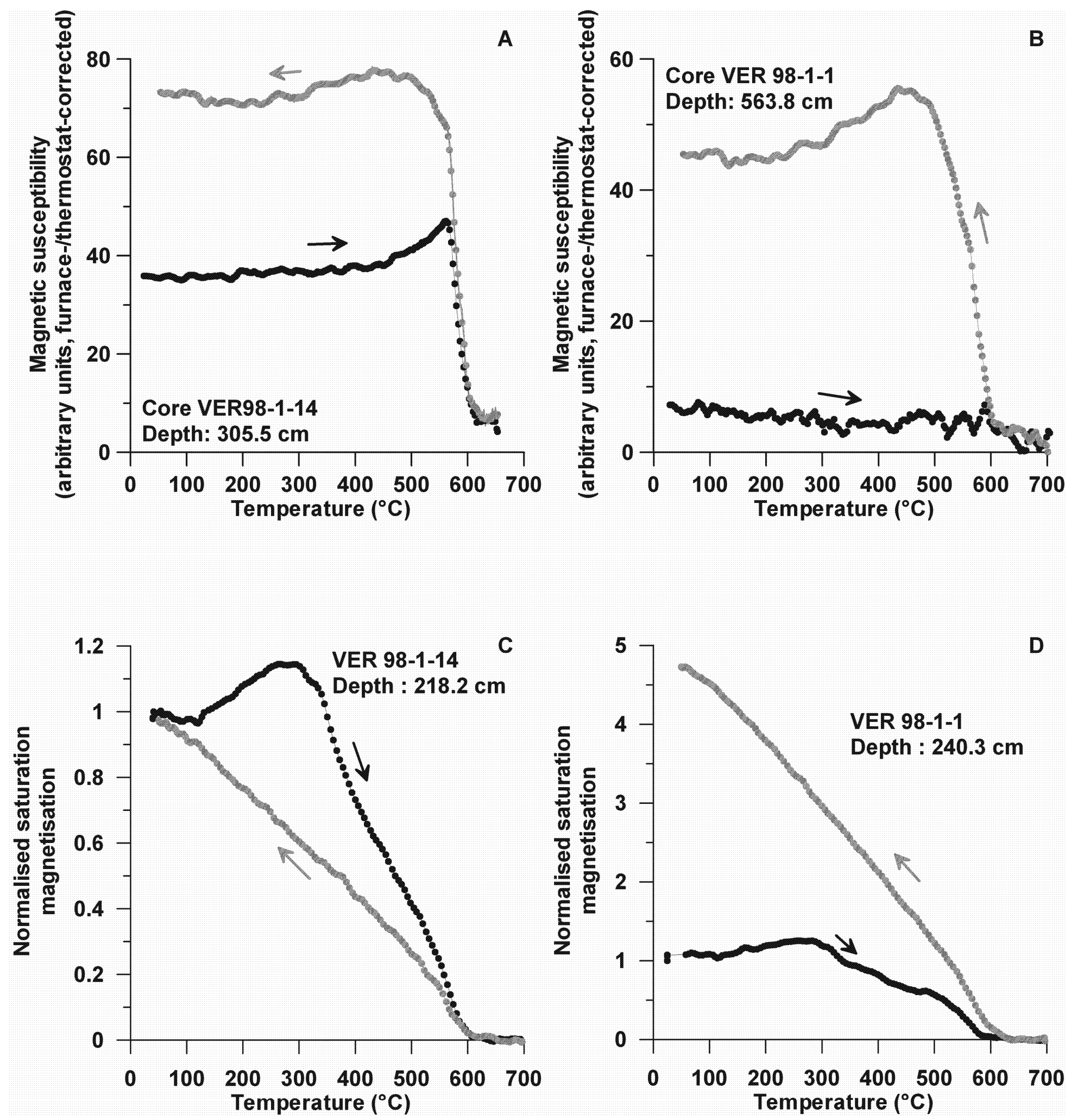


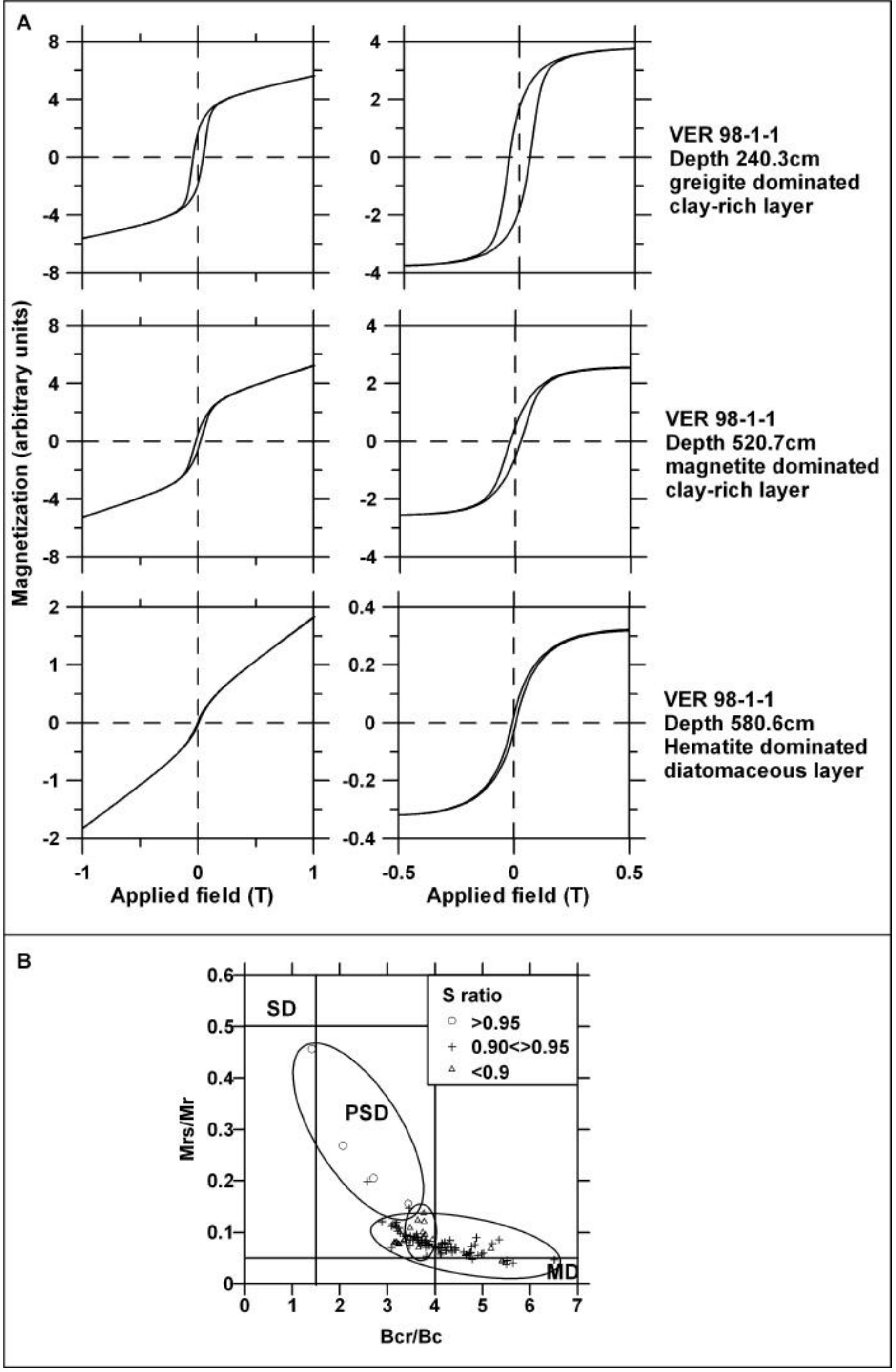



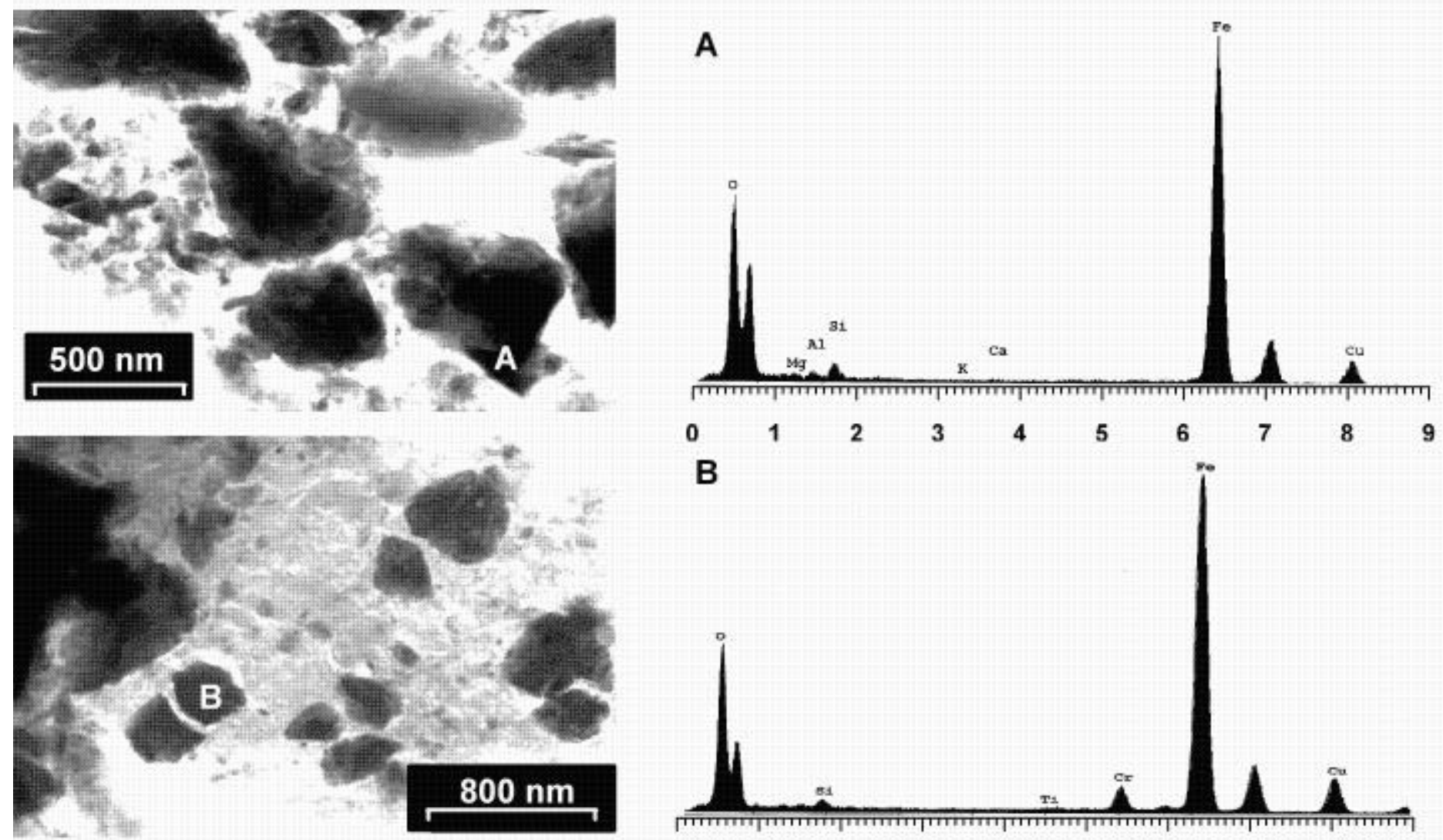

B
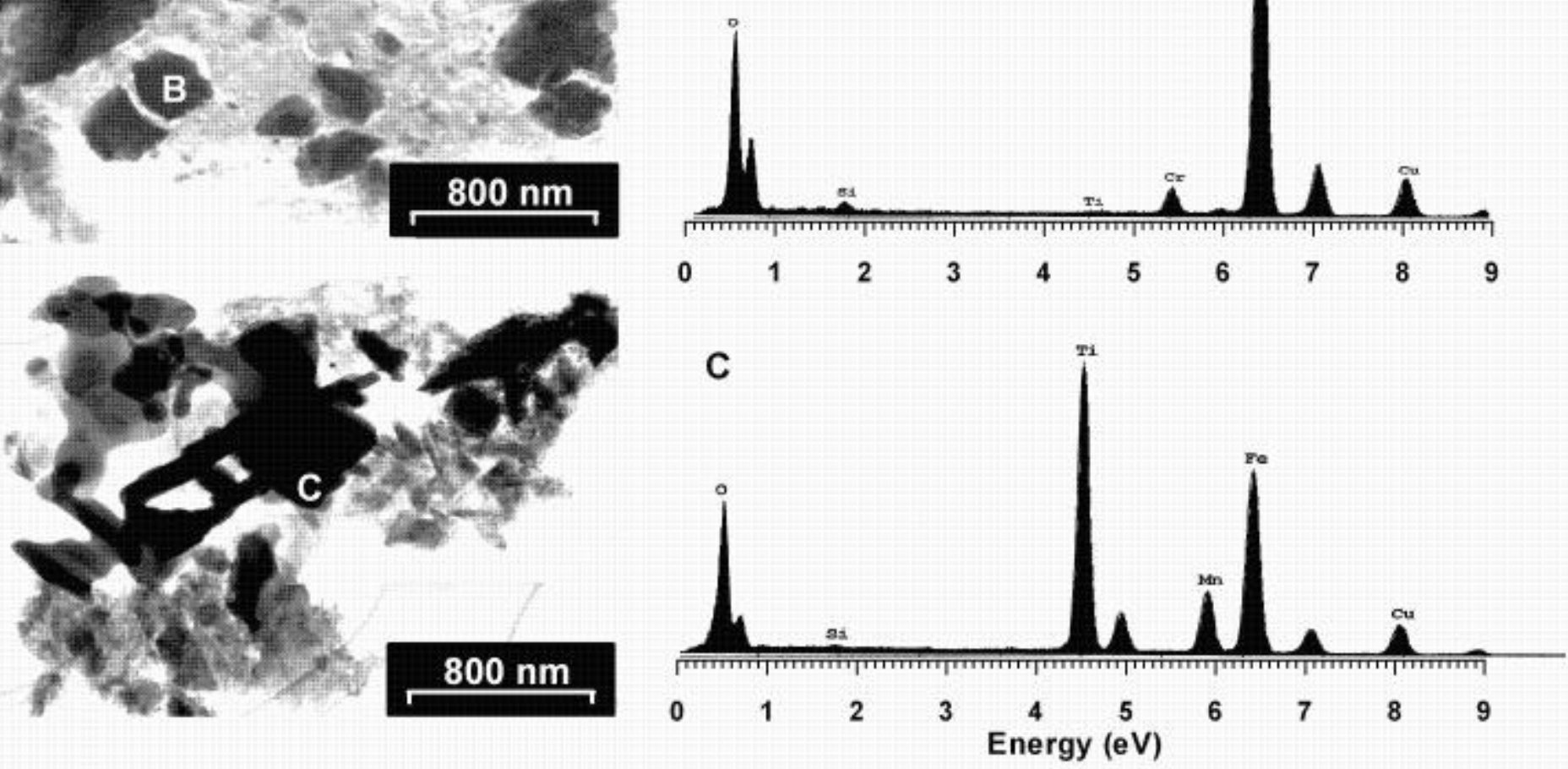
A

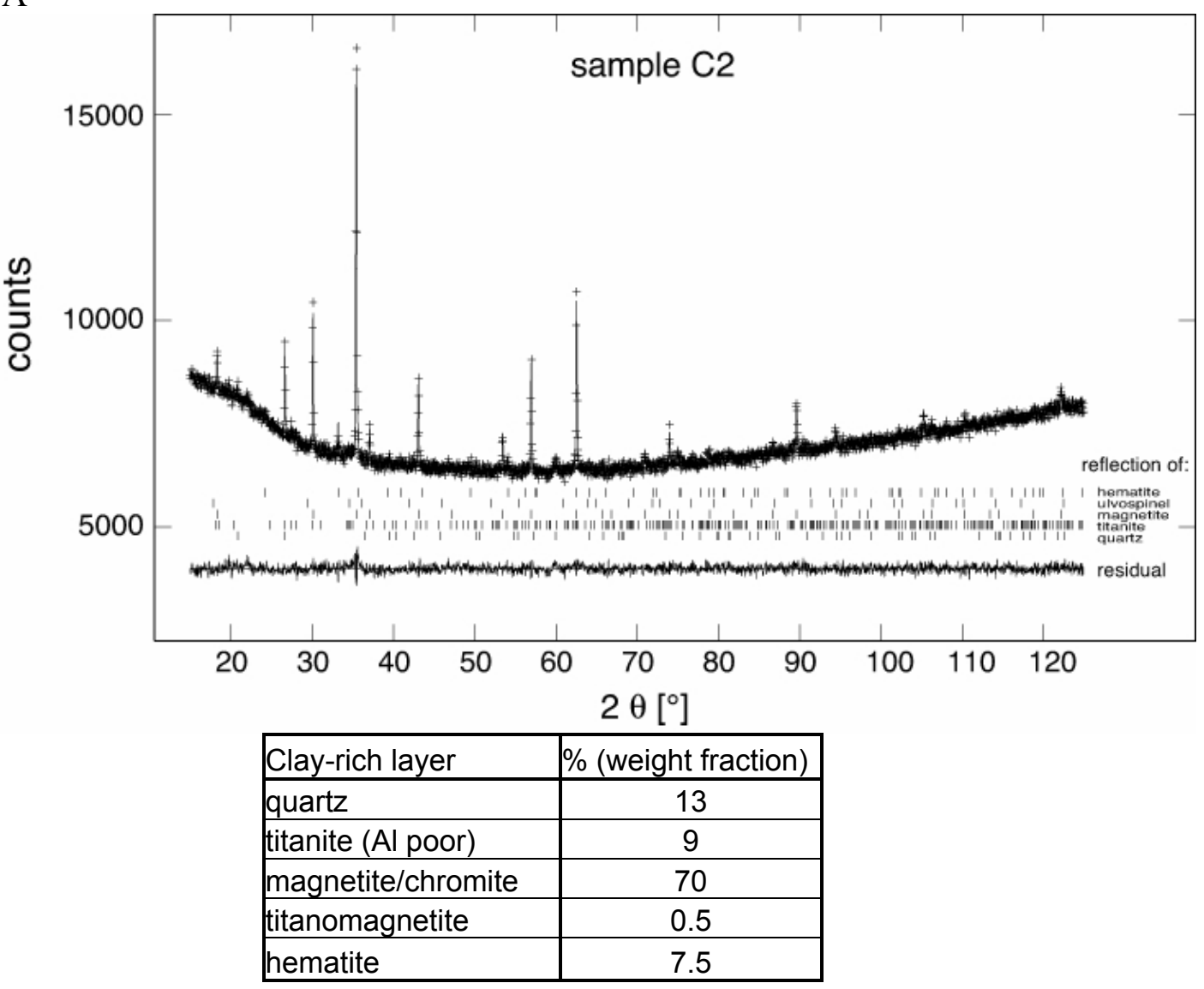

B

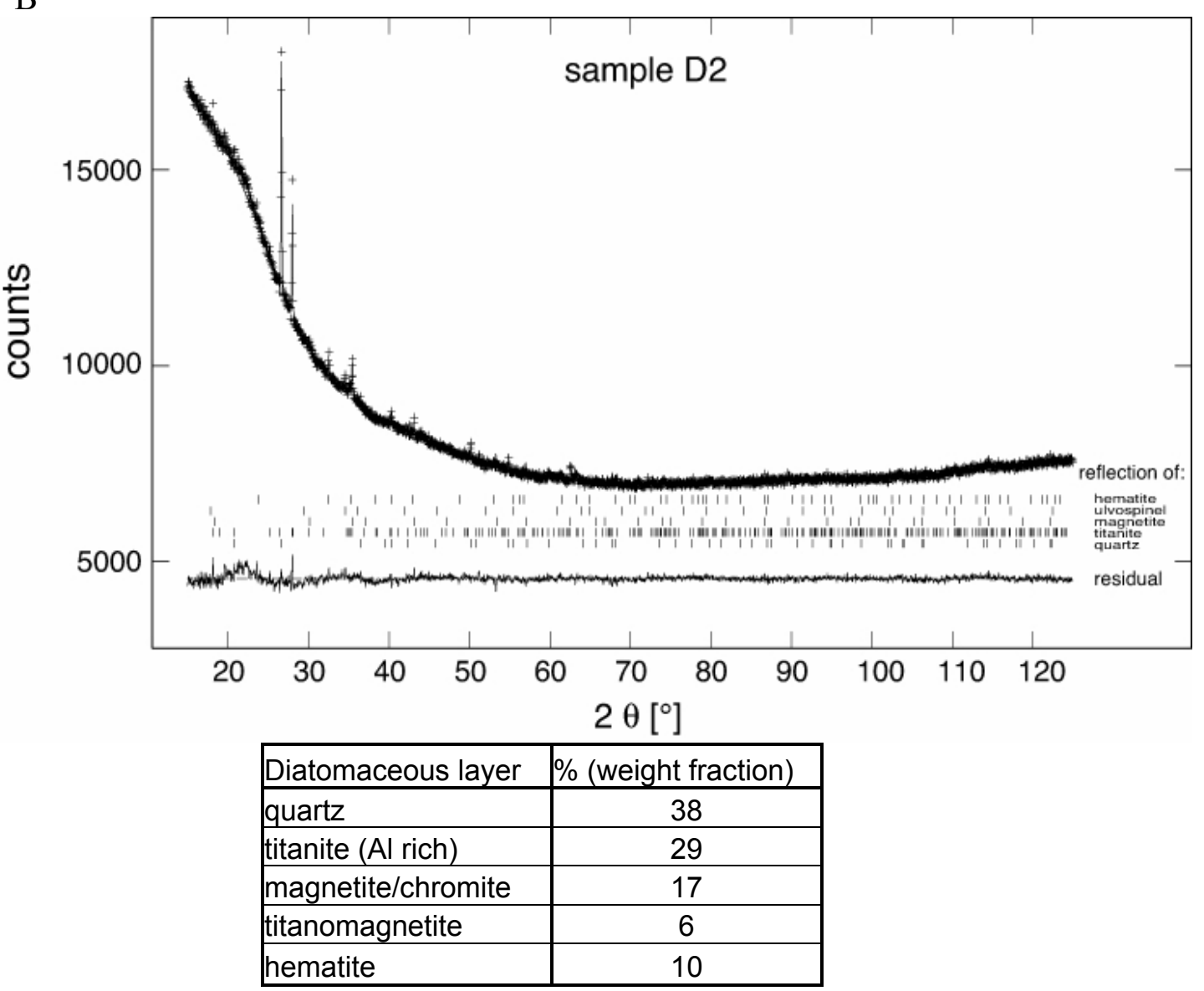

Fig. 8 


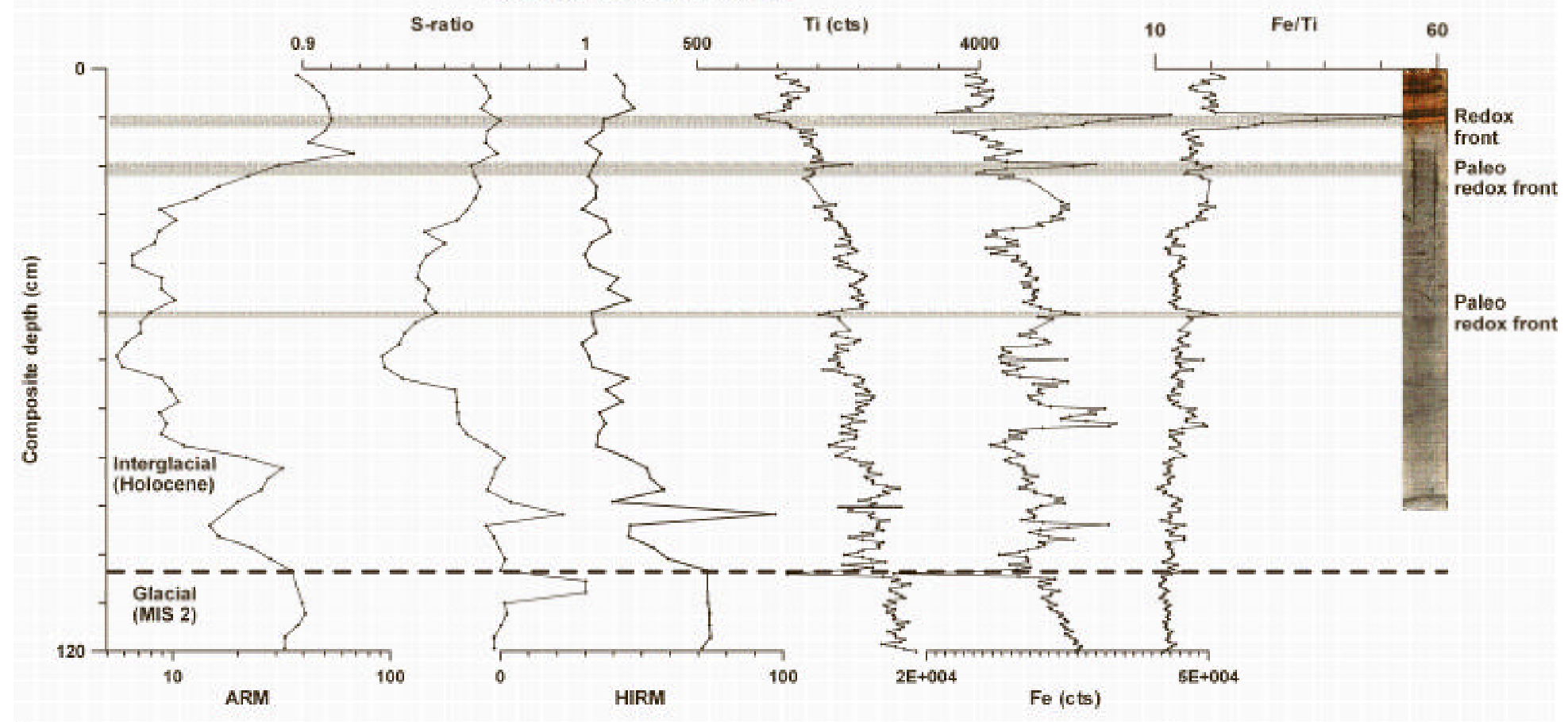

B

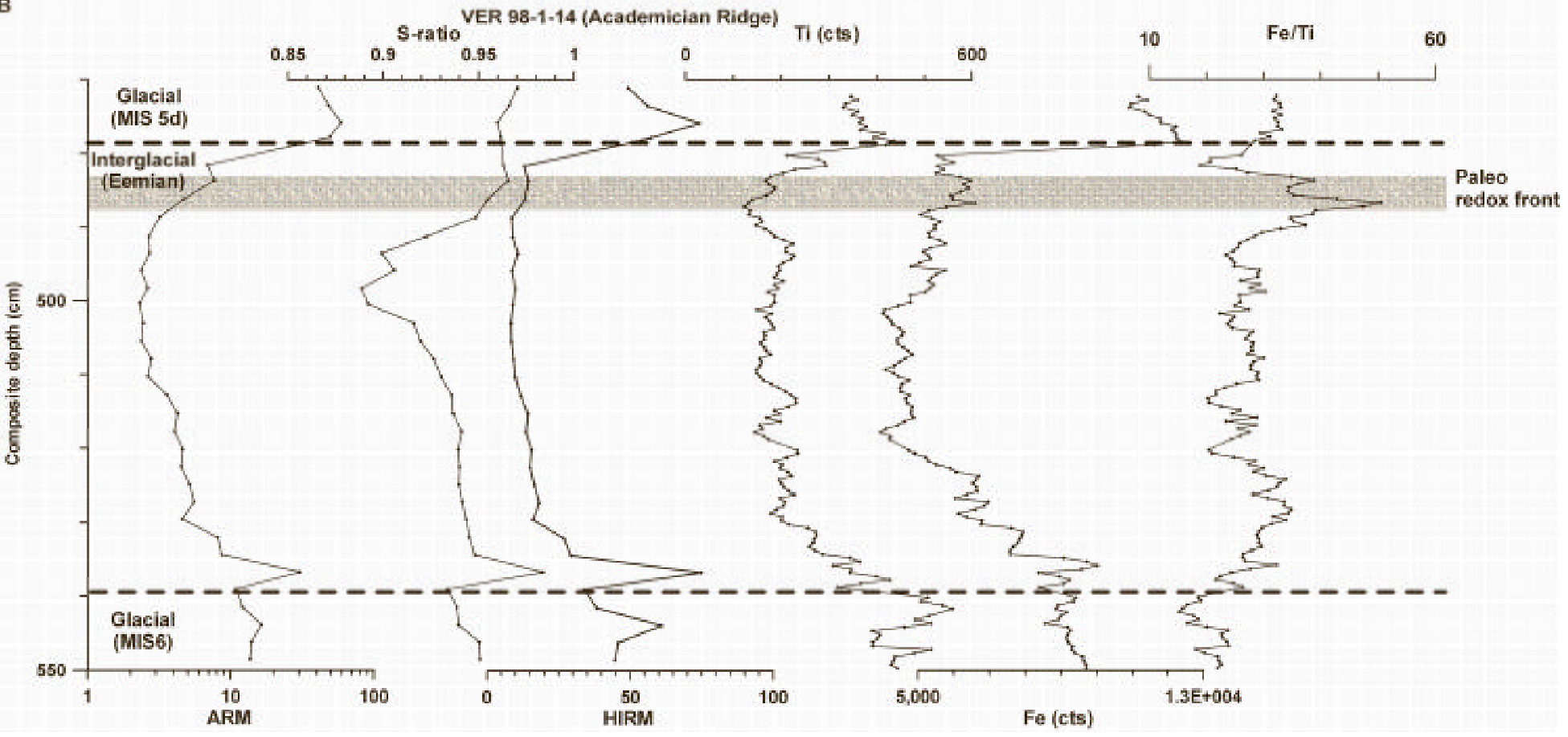




\section{S-ratio}

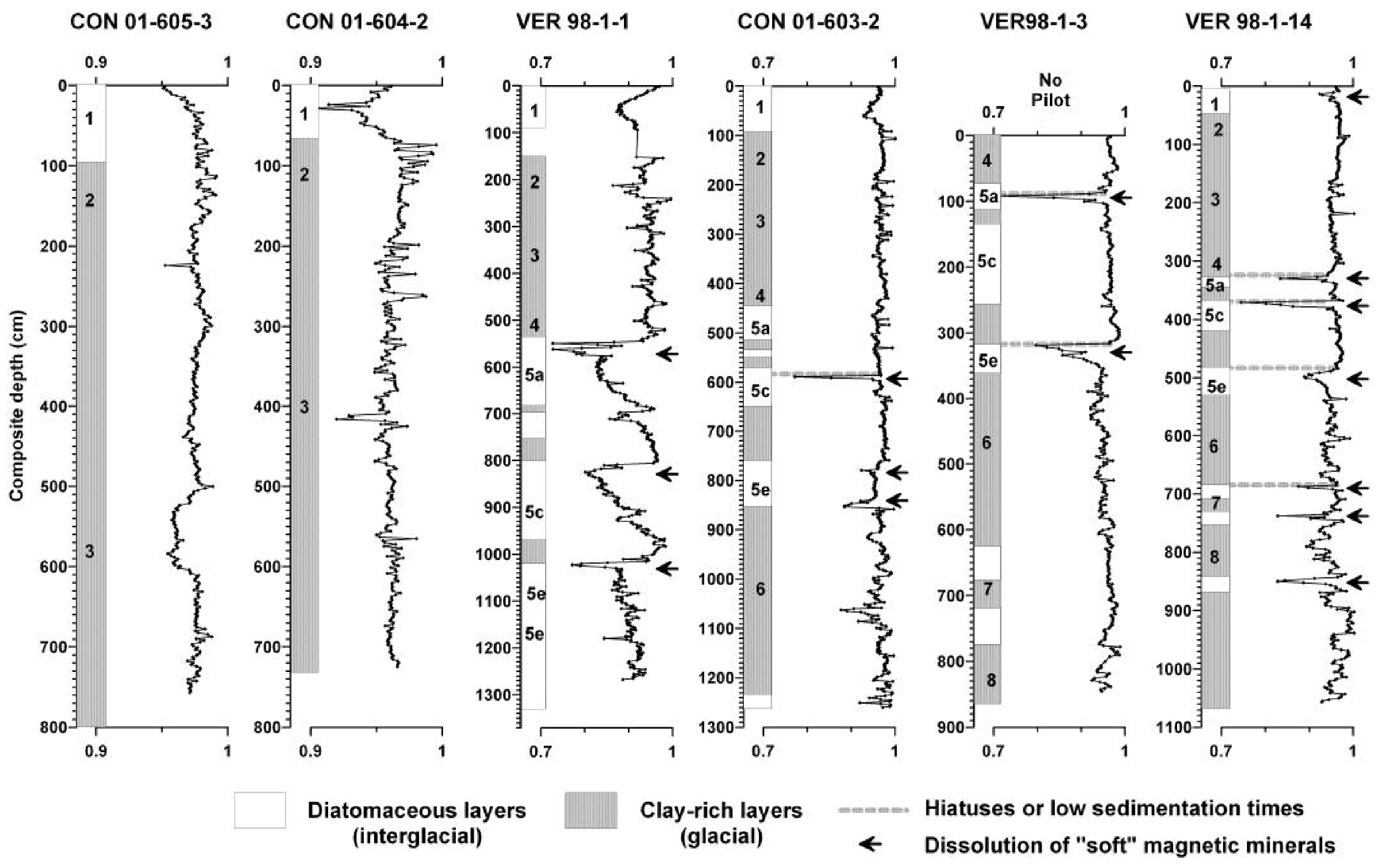




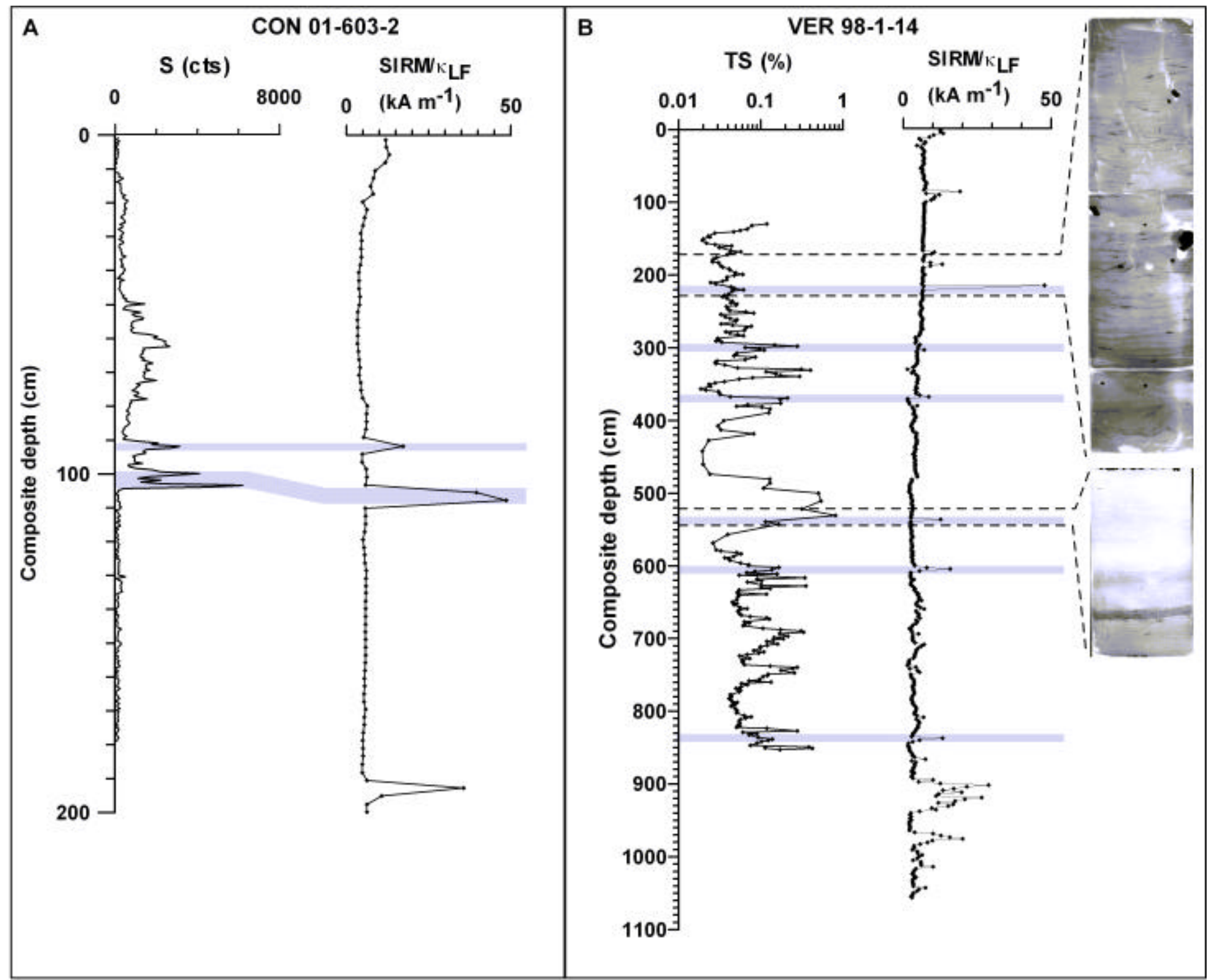

Fig. 11 
$\operatorname{SIRM} / \kappa_{\mathrm{LF}}$

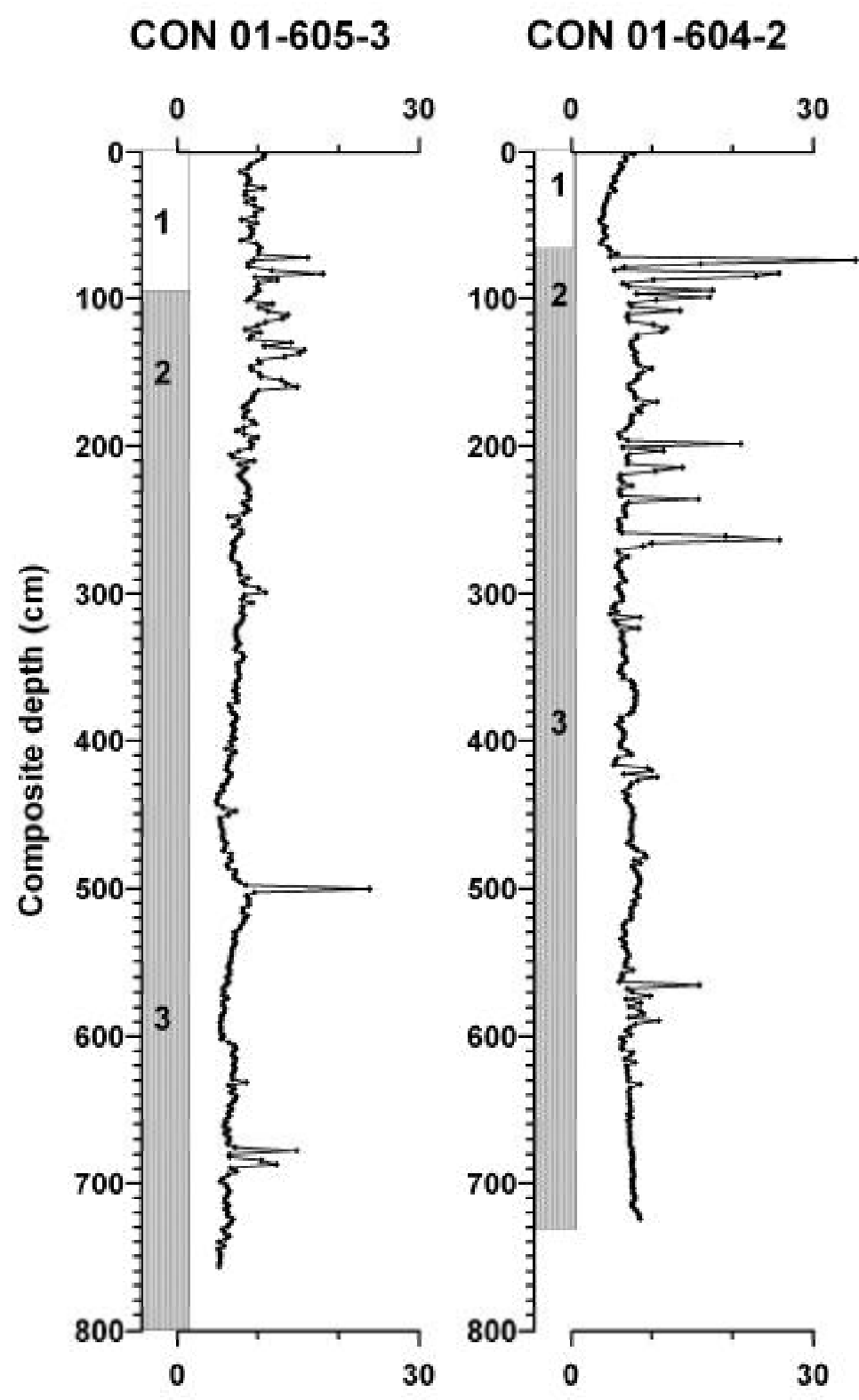

VER 98-1-1
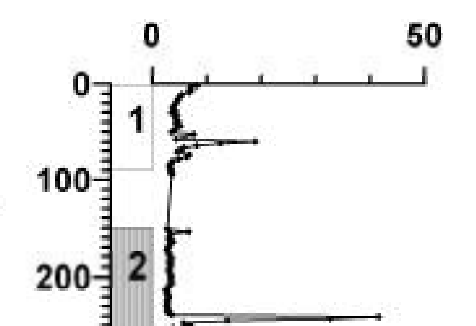$$
300
$$

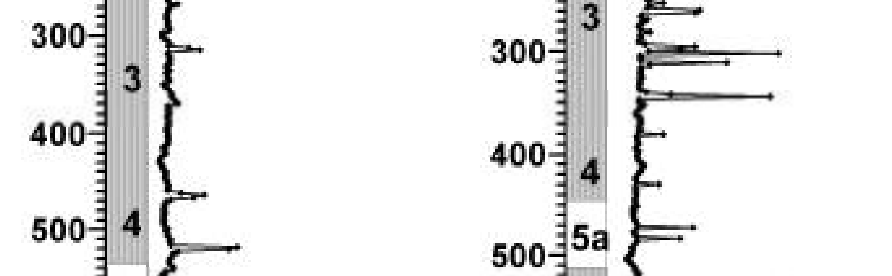

$$
600
$$
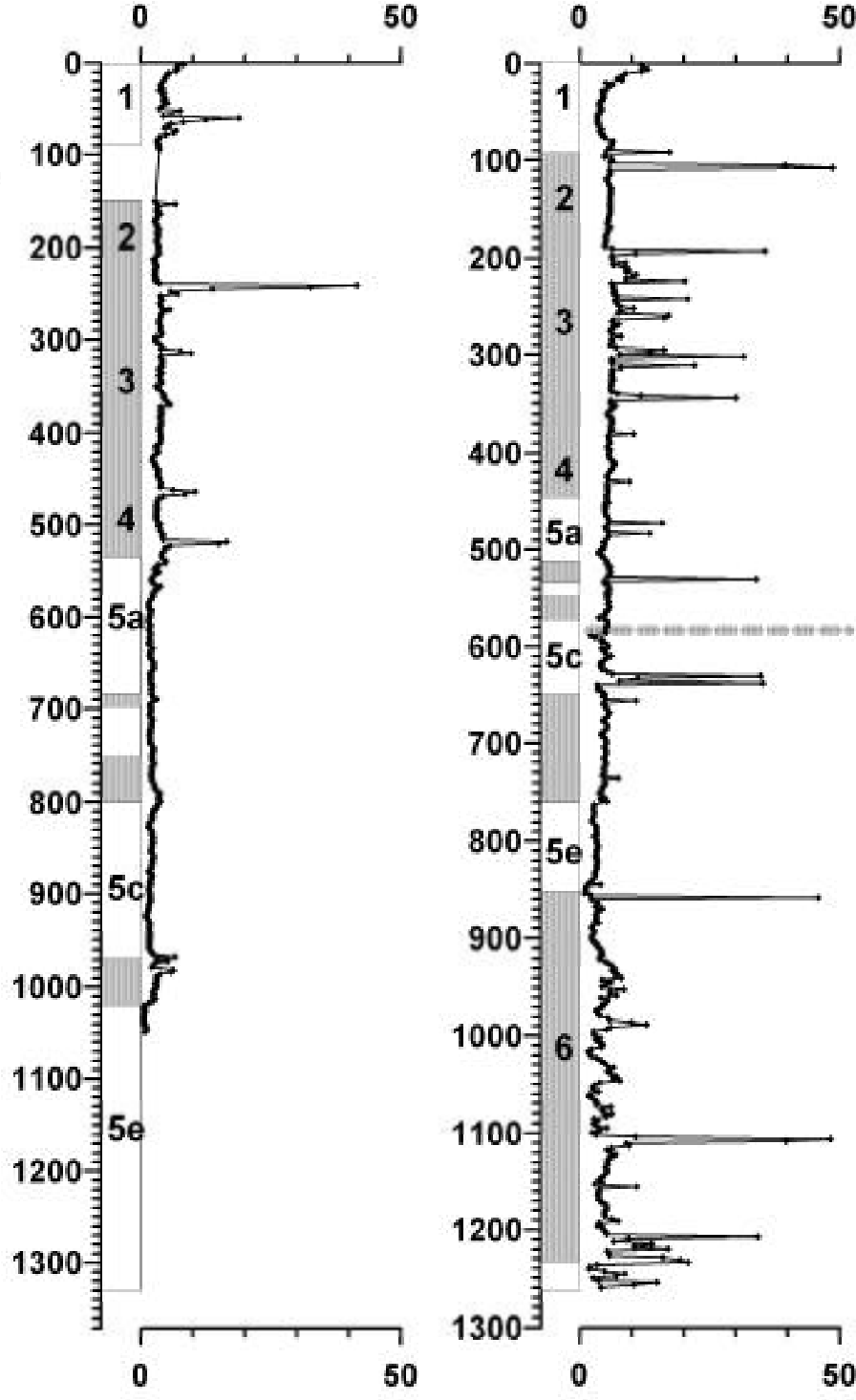

VER98-1-3

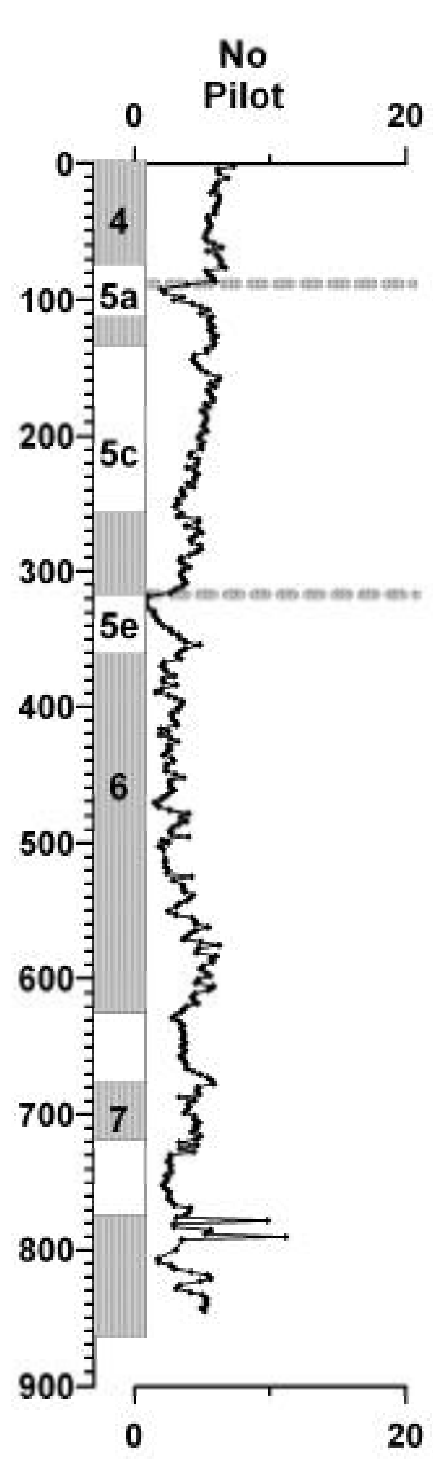

VER 98-1-14

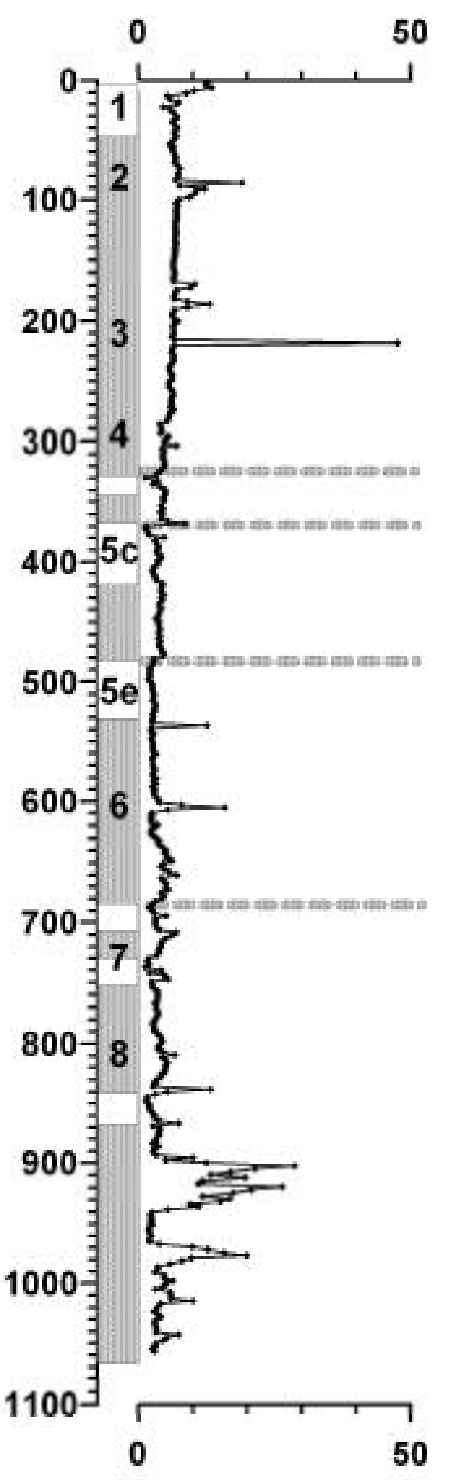

Diatomaceous layers 